\title{
Q2 Cenozoic evolution of the Qaidam basin and implications for the growth of the northern Tibetan plateau: A review
}

(i) The corrections made in this section will be reviewed and approved by a journal production editor.

[Instruction: Add a third affilation to Feng Cheng.Thus, the authors and affiliation should be changed to: Feng

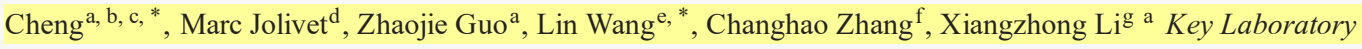
of Orogenic Belts and Crustal Evolution, Ministry of Education, School of Earth and Space Sciences, Peking

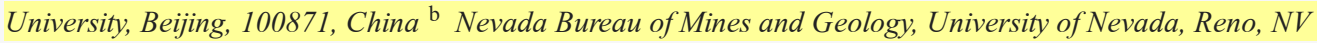
89557, USA ${ }^{c}$ Lhasa National Geophysical Observation and Research Station, Institute of Geology, China Earthquake Administration, Lhasa 850004, China ${ }^{\text {d }}$ Laboratoire Géosciences Rennes, CNRS-UMR6118, Université Rennes 1, Observatoire des Sciences de l'Univers, Rennes, 35042, France e College of Engineering, Peking University, Beijing 100871, China ${ }^{\mathrm{f}}$ Qinghai Oilfield Company, PetroChina, Dunhuang, Gansu, 736202 , China ${ }^{\mathrm{g}}$ Yunnan Key Laboratory of Earth System Science, Yunnan University, Kunming, 650500, China] Feng Cheng ${ }^{\mathrm{a}, \mathrm{b}, *}$ cfcf.chengfeng@gmail.com, Marc Jolivet ${ }^{\mathrm{c}}$, Zhaojie Guo ${ }^{\mathrm{a}}$, Lin Wang ${ }^{\mathrm{d}, *}$ linzi@pku.edu.cn, Changhao Zhang ${ }^{\mathrm{e}}$, Xiangzhong $\mathrm{Li}^{\mathrm{f}}$

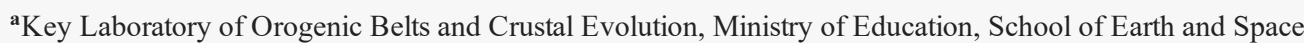
Sciences, Peking University, Beijing 100871, China

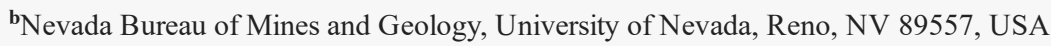

'Laboratoire Géosciences Rennes, CNRS-UMR6118, Université Rennes 1, Observatoire des Sciences de l'Univers, Rennes 35042, France

${ }^{\mathbf{d}}$ College of Engineering, Peking University, Beijing 100871, China

${ }^{e}$ Qinghai Oilfield Company, PetroChina, Dunhuang, Gansu 736202, China

fYunnan Key Laboratory of Earth System Science, Yunnan University, Kunming 650500, China

*Corresponding authors.

\begin{abstract}
As the largest depression in the Tibetan plateau, the Qaidam basin preserves over $10 \mathrm{~km}$ thick of Cenozoic sediments. Those sediments represent a unique archive of the evolution of the northern part of the Tibetan plateau and of intracontinental deformation in general. Yet, several critical issues associated with the evolution of the Qaidam basin remain controversial, preventing a full understanding of the evolution of the northern margin of Tibet during the Cenozoic. Here we comprehensively review these issues, synthesize records from structural geology, sedimentology, geochronology, and geophysics, and finally propose a holistic view of the Cenozoic evolution of the Qaidam basin. We infer that: 1) the traditional age model that assigned a Paleocene to Eocene basal age to the Cenozoic strata in the basin seems to fit reasonably well the deformation history obtained from combining growth-strata observations and thermochronology data across the basin; 2) basement-involved faults, with both dip-slip and strike-slip components, developed within the Qaidam basin. In particular, the Neogene initiation of strike-slip faulting along the south-dipping faults that roots into the Eastern Kunlun Shan played an important role in the evolution of the southern Qaidam basin; 3) The Eastern Kunlun Shan was already exhumed during the deposition of the Lulehe Formation, serving as a significant source of clastic material deposited in the Qaidam basin and separating the latter from the Hoh Xil basin to the south. We conclude that the Qaidam basin is a superimposed sedimentary basin that successively experienced flexural subsidence, outwards expansion, isolation and partitioning during the Cenozoic. Finally, the Cenozoic evolution of the basin results from a tight interplay between tectonics and climate.
\end{abstract}


Cenozoic, Qaidam basin, Northern Tibetan plateau, Tectonic evolution, Tectonics-climate interplay

\section{Q7 1.1 Introduction}

Our knowledge of the growth of the Tibetan plateau has progressed over the last few decades, mostly by depicting in details the Cenozoic tectonic and topographic evolution of the several mountains belts and associated fault systems that compose the plateau (Ding et al., 2014; Hubbard and Shaw, 2009; Jolivet et al., 2001; Lease, 2014; Tapponnier et al., 2001; Wang et al., 2014; Yin et al., 2002). A particular interest has been addressed to the margins of the plateau - the locus of the outward expansion of the high-topography region - characterized by active tectonic deformation and sharp topographic and climatic gradients. Several substantial breakthroughs have been achieved in dating, describing and quantifying the Cenozoic deformation of the northern edge of the Tibetan plateau. One of the first widely accepted model argued that crustal deformation in the northern Tibetan plateau initiated during the Pliocene to Holocene, progressively propagating northward (Métivier et al., 1998; Meyer et al., 1998; Tapponnier et al., 2001). However, recent work highlights a protracted Cenozoic deformation history initiating during Early Cenozoic, progressing through the Oligocene to Early Miocene, and accelerating in the Middle Miocene to Holocene-Quaternary times (Cheng et al., 2015a; Clark et al., 2010; Dupont-Nivet et al., 2004; Duvall et al., 2013; Duvall et al., 2011; Jolivet et al., 2001; Lease et al., 2012; Yin et al., 2002; Zheng et al., 2010; Zhuang et al., 2011b). These new findings are in conflict with the progressively northward propagation model, highlighting an urgent need for a better understanding of the mechanisms that drove the growth of the plateau.

The northern Tibetan plateau is composed of a series of high topographic gradient mountain ranges surrounding the large and deep Qaidam sedimentary basin (Fig. 1). Being the largest Cenozoic sedimentary basin within the Tibetan plateau, the Qaidam basin is bordered by the Altyn Tagh Shan to the west, the Eastern Kunlun Shan to the south, and the Qilian Shan to the northeast (Figs. 1-2). Geological and subsurface surveys reveal that the basin preserves Cenozoic sedimentary successions reaching over $10 \mathrm{~km}$ in thickness (Cheng et al., 2018; Cheng et al., 2017; Wei et al., 2016; Xia et al., 2001; Yin et al., 2008b; Zhang et al., 2013a; Zhu et al., 2006). These clastic deposits contain some major hydrocarbon resources and the numerous field-derived and geophysical data resulting from exploration offer a unique opportunity to elucidate the evolution of the basin itself but also the growth history of the surrounding mountain belts. However, three critical issues associated with the tectonic and sedimentary evolution of the Qaidam basin remain controversial, leading to diverse and even competing models for the Cenozoic evolution of northern Tibet.

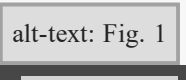

Figure 1.Fig. 1

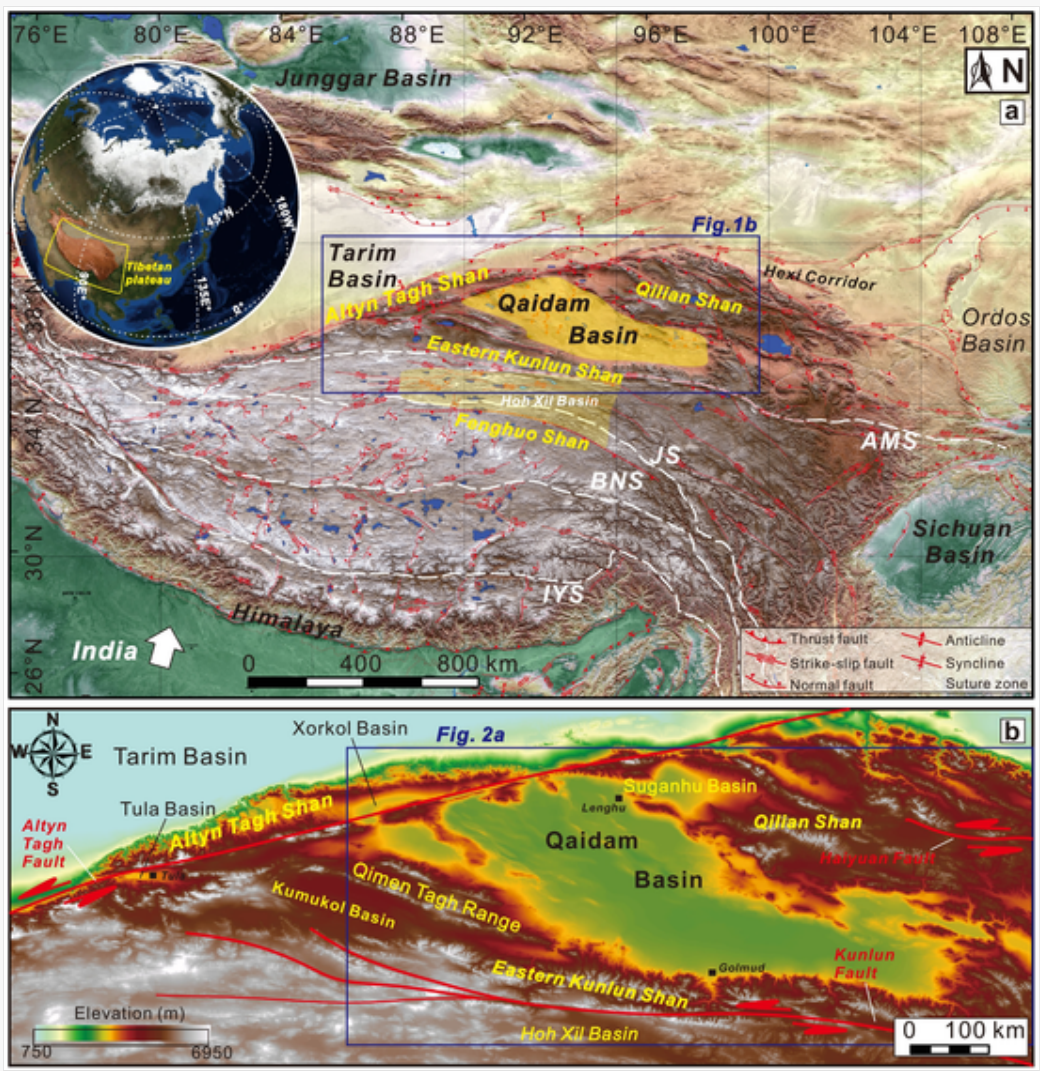




\section{alt-text: Fig. 2}

Figme 2.Fig. 2

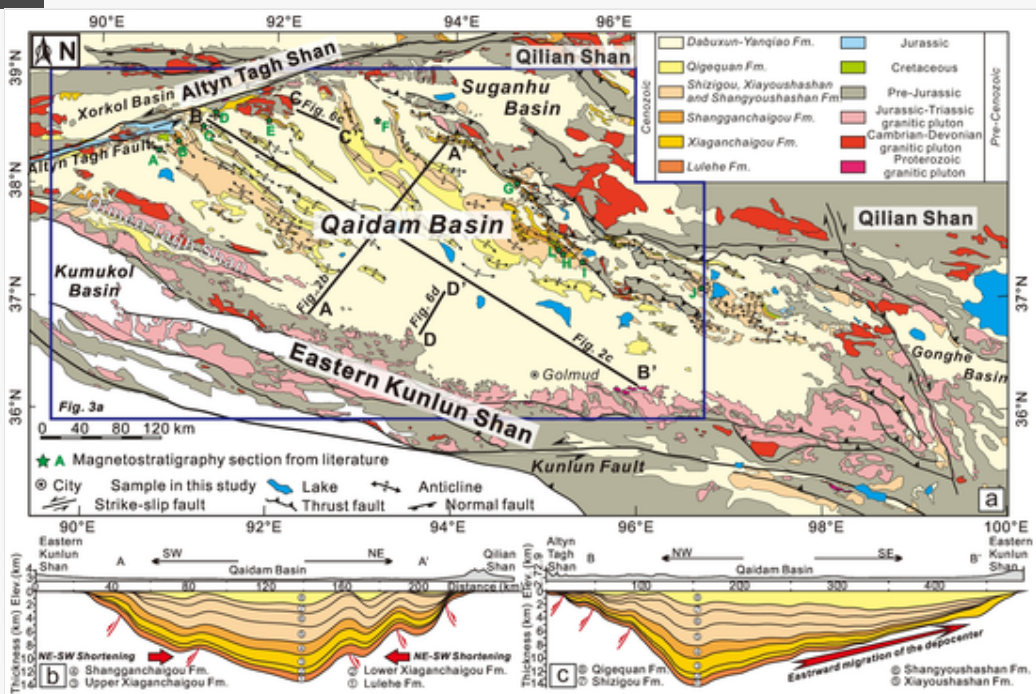

(a) Geological map of the Qaidam basin and the surrounding regions. (b) NE-SW- and (c) NW-SE-oriented profiles across the Qaidam basin, modified from Cheng et al. (2018). Note the NE-SW-directed crustal shortening across the Qaidam basin and eastward migration of the depocenter of the basin during the Cenozoic.

First, the age model for the Cenozoic strata within the Qaidam basin is highly debated. Most studies based on magnetostratigraphy, spore and pollen assemblages, fission-track and ${ }^{40} \mathrm{Ar} /{ }^{39} \mathrm{Ar}$ dating of detrital grains as well as regional lithostratigraphic correlations assigned a Paleocene basal age (>50 Ma) to the Lulehe Formation (Fm.) that represents the lowermost part of the Cenozoic sequence (Chang et al., 2015; Fang et al., 2019; Fang et al., 2006; Fang

Q8 et al., 2007; Ji et al., 2017; Ke et al., 2013; Lu and Xiong, 2009; Rieser et al., 2006a; Rieser et al., 2006b; Sun et al., 1999; Sun et al., 2005; Yang et al., 1992; Zhang, 2007). By contrast, a few recent studies proposed a Late Oligocene $(\sim 25=-20 \mathrm{Ma})$ onset of sedimentation based on magnetostratigraphical constraints from two sections exposed along the northern margin of the basin (Fig. 2). When adopting the older age model with a Paleocene to Eocene deposition age of the Lulehe Fm., the Cenozoic onset time of faulting along the Altyn Tagh Fault and the northern Qaidam basin-Qilian Shan thrust belt becomes roughly coincident with the onset of India-Asian collision at 60- $50 \mathrm{Ma}$ (Cheng et al., 2019a; Cheng et al., 2019c; Cheng et al., 2015b; Cheng et al., 2016b; Cheng et al., 2019d; Dupont-Nivet et al., 2010; Hu et al., 2015; Yin et al., 2008a; Yin et al., 2008b). This inference of an Early Cenozoic deformation in the northern Tibetan plateau supports the argument that stress derived from India-Asia collision was transmitted rapidly to the northern edge of the plateau (Clark et al., 2010; Jolivet et al., 2001; Wang et al., 2017a; Yin et al., 2002; Zhuang et al., 2011b). Furthermore, if Paleocene to Eocene crustal shortening took place in the northern Tibetan plateau, mountain belts would probably have formed orographic barriers, starting to block the transfer of atmospheric moisture to the continental interior as early as the Early Cenozoic. This would be consistent with the already semi-arid to arid climate recorded in the Tarim basin during the Paleogene (Heilbronn et al., 2015; Jolivet et al., 2018; Sun and Wang, 2005). On the contrary, if considering an Oligocene deposition age for the Lulehe Fm., the onset time of deformation in the Altyn Tagh Shan and Qilian Shan would be similar to that of exhumation in the Eastern Kunlun Shan, Xining-MinheLongzhong basin complex and Dangchang basin (Clark et al., 2010; Dupont-Nivet et al., 2008; Dupont-Nivet et al., 2004; Horton et al., 2004). Based on this model, the initial deformation in the northern Tibetan plateau would start about 15--20 Ma later than the onset of India-Asia collision. This would fit with the model proposing a gradual northward propagation of the deformation in the plateau (Meyer et al., 1998; Tapponnier and Molnar, 1977; Tapponnier et al., 2001; Wang et al., 2017b). If topographic growth had remained limited in the northern Tibetan plateau during the Early Cenozoic, atmospheric circulation would probably not have been strongly affected, and the climate change in the Asian interior during the Early Cenozoic should be largely linked to other factors, such as the global climate variation or the retreat of the Paratethys sea (Bosboom et al., 2014; Dupont-Nivet et al., 2007; Meijer et al., 2019). As a consequence, it is of great importance to confirm the age model for the Cenozoic strata in the Qaidam basin. 
plateau (e.g., progressive northward, out of sequence, or pulsed deformation). Comparing the stratigraphic architecture of the Cenozoic strata in the Qaidam basin with those of the Hoh Xil basin immediately to the south, Yin et al. (2008b) proposed the existence of a wide Paleo-Qaidam basin. Their model suggested a vast Early Cenozoic depression bounded by the Qilian Shan to the north and by the Fenghuo Shan Thrust Belt to the south with negligible topographic relief in the Eastern Kunlun Shan This model has been followed by many researchers (Fig. 1)(McRivette et al., 2019; Wu et al., 2019b). However, other studies have indicated that the Eastern Kunlun Shan might have already been exhumed during the Early Cenozoic (Cheng et al., 2016a; Cheng et al., 2019a; Wang et al., 2014), which would suggest that the similar stratigraphic architecture of the Qaidam and Hoh Xil basins is only due to a similar depositional environment. Given that the crux of the debate is a dispute over the uplift history of the Eastern Kunlun Shan, it is of primary importance to document the evolution of the topography and the structural relation between the Qaidam basin and the Eastern Kunlun Shan.

The third open question is the Cenozoic evolution history of the Qaidam basin and the associated growth history of the northern Tibetan plateau. This issue is closely related to the abovementioned two issues. For instance, a Paleocene basal age ( $>50 \mathrm{Ma}$ ) for the Cenozoic strata in the basin would partly support the distributed shortening model (Dewey and Bird, 1970; England and Searle, 1986). However, a late Oligocene basal age ( 25=-20 Ma) would support the outward growth or northward propagation model (Métivier et al., 1998; Meyer et al., 1998; Tapponnier et al., 2001; Wang et al., 2017b; Zheng et al., 2017). In addition, the Paleo-Qaidam basin model requires an Early Cenozoic onset of deformation in the Qilian Shan to the north and a Neogene initiation of the deformation in the Eastern Kunlun Shan to the south. This would imply deformation first in the northern margin of the Tibetan plateau, partially skipping the Easter Kunlun Shan shortly after India-Asia collision (Yin et al., 2008a; Yin et al., 2008b). On the other hand, other studies proposed a synchronous deformation in both the Eastern Kunlun Shan and the Qilian Shan to the north (Cheng et al., 2016a; Cheng et al., 2019a; Wang et al., 2014), again indicating distributed crustal deformation across the northern Tibetan plateau.

In this contribution, we focus on the first two critical issues by summarizing recent studies that provide different views on these issues and discussing the advantages and limitations of each hypothesis, and we propose future directions of investigation. We synthesize available information from subsurface data interpretation (i.e., seismic profiles and isopach maps of Cenozoic strata), sedimentology, stratigraphy, and basin analysis to present a holistic view of the Cenozoic evolution of the Qaidam basin.

\section{z.2. Geological setting}

The granitic and metamorphic crystalline basement of the Qaidam basin is covered by a relatively thin (less than $3 \mathrm{~km}$ ) and discontinuous Mesozoic sedimentary sequence and a huge, as thick as $10 \mathrm{~km}$ Cenozoic sequence (Figs. 2, 3a and 4 )(Liu et al., 2007b; Meng and Fang, 2008; Rieser et al., 2006b; Xia et al., 2001; Yin et al., 2008a; Yin et al., 2008b; Zhou et al., 2006). Recent studies showed that the Qaidam basin and the surrounding orogenic belts share a similar basement composition (i.e., similar geochemistry and U-Pb zircon age spectra) (Cheng et al., 2017) (Fig. 3b-f). The Qaidam crystalline basement was involved in at least Neoproterozoic, Early Paleozoic, and Late Paleozoic to Mesozoic tectono-magmatic episodes (Cheng et al., 2017). These recurrent thermo-mechanical events generated weaknesses in the Qaidam basement that should therefore not be considered as a mechanically strong crust. Detailed description of the basement is given in the Supplementary materials. 


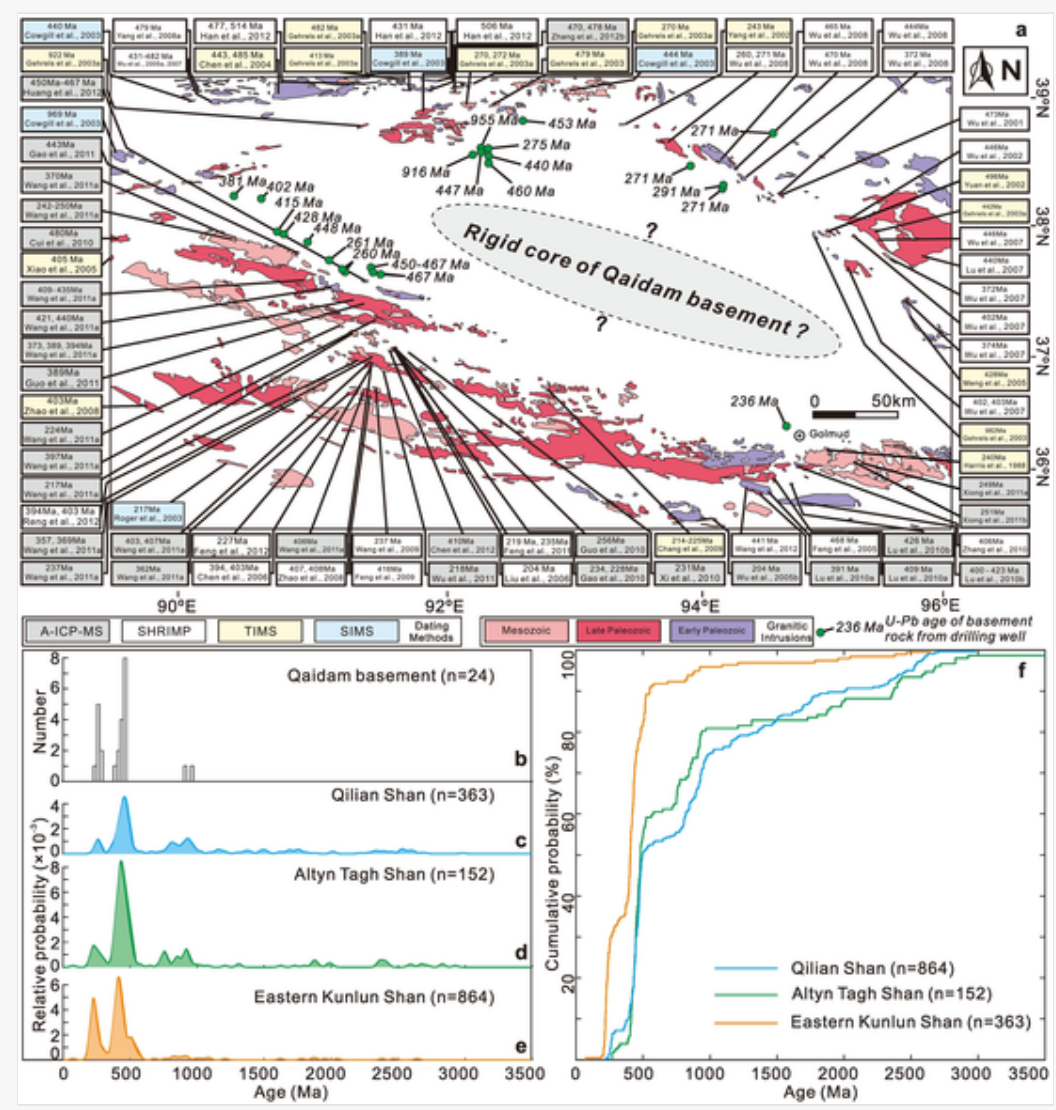

(a) Zircon U-Pb ages for granitoids showing the distribution of Proterozoic to Mesozoic intrusions in the Qaidam basin and surrounding orogenic belts. Note the age of the Qaidam basement rocks along the edges of the basin (Cheng et al., 2017). The relative probability plot of the U-Pb zircon ages from basement rocks in the Qaidam basin (b), Qiilian Shan (c), Altyn Tagh Shan (d), and Eastern Kunlun Shan (e). Cumulative probability plot for these data is shown in (f). Data and references listed are from Cheng et al. (2017) and references therein.

alt-text: Fig. 4

Figure 4,Fig. 4

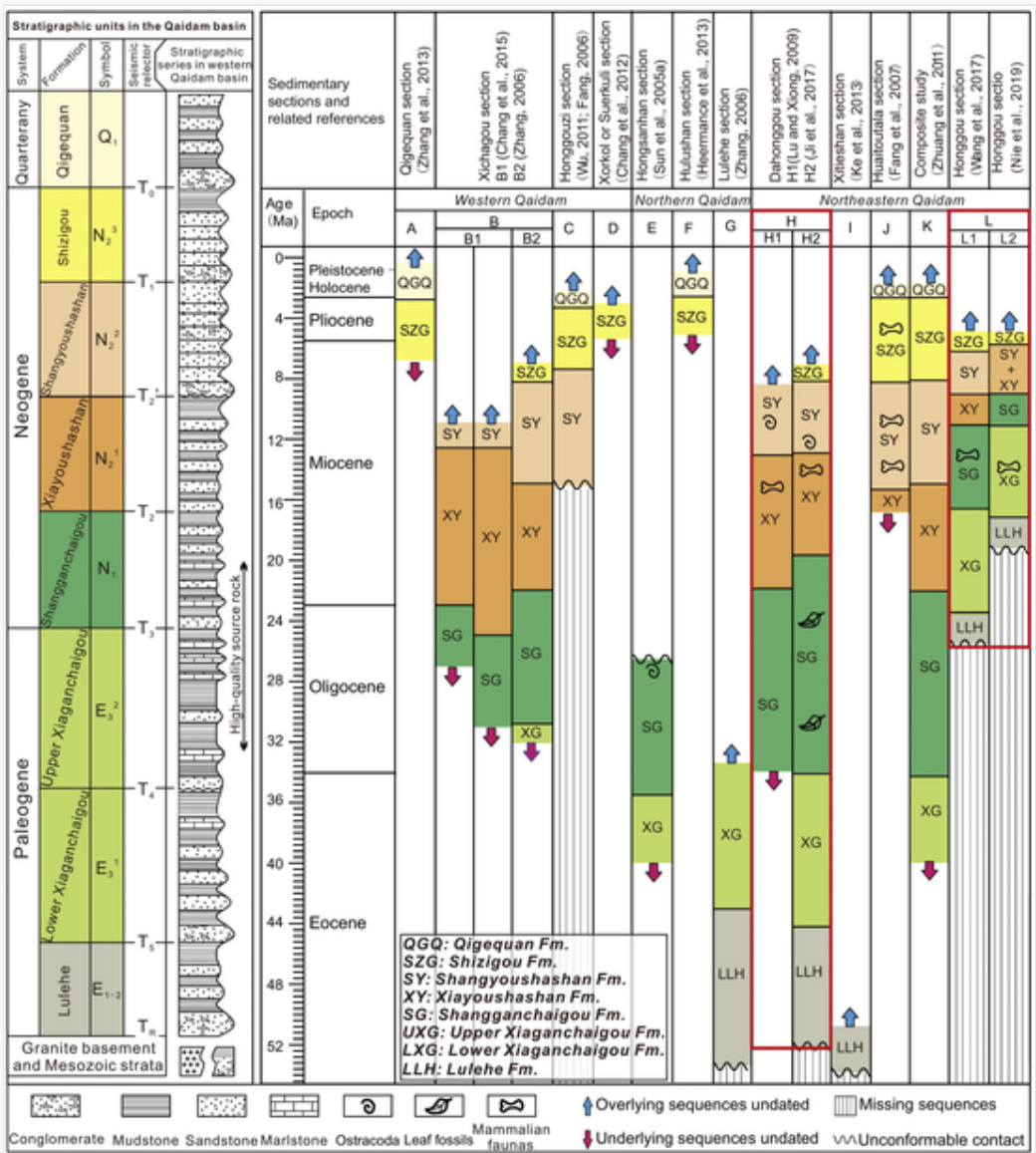


Lithology, lithostratigraphic units, and age models of the Cenozoic strata in the Qaidam basin. The stratigraphic column is representative of the lithology in the western Qaidam basin, modified from Cheng et al. (2018). The multiple age models are modified from the compilation of (Wu et al., 2019b). These age models were established by previous work from different sections in the basin(Chang et al., 2012; Chang et al., 2015; Fang et al., 2006; Fang et al., 2007; Heermance et al., 2013; Ji et al., 2017; Ke et al., 2013; Lu and Xiong, 2009; Nie et al., 2019; Sun et al., 2005; Wang et al., 2017b; Wu, 2011; Zhang, 2007; Zhang et al., 2013b; Zhuang et al., 2011b). The location of each section is shown in Figure 2a.]Images of typical outcrops and drill cores samples of Mesozoic to Cenozoic strata and basement rocks in the Qaidam basin. (a) Unconformities between the Jurassic and Cretaceous strata in the NE Qaidam basin. (b) Marginal lacustrine coal-bearing Jurassic srata in the NE Qaidam basin. (c) Drilling core samples in the NE Qaidam basin, showing coarse-grained sandstone in the Lulehe Fm. and granite basement rocks. (d) Conglomerates in the Lulehe Fm., eastern Qaidam basin. (e) Lacustrine limestone in the Lower Xiaganchaigou Fm., western Qaidam basin. (f) Organic rich layers in the Upper Xiaganchaigou Fm., western Qaidam basin. (g) Lacustrine to fluvial deposits in the Shangganchaigou Fm., eastern Qaidam basin. (h) Lacustrine sequences in the Xiayoushashan Fm., western Qaidam basin. (i) Mega-yardangs sculpted in mainly lacustrine Shizigou Fm. and fluvial Qigequan Fm., NE Qaidam basin.

Mesozoic strata are Jurassic and Cretaceous in age (Cheng et al., 2019d; Meng et al., 2001; QBGMR, 1991; Ritts and Biffi, 2000; Ritts and Biffi, 2001; Ritts et al., 1999; Wu et al., 2011). These clastic, continental deposits mainly consist of sandstone intercalated with shale, coal, and conglomerate associated to fluvial to lacustrine depositional environments (Fig. 4a-b). The Mesozoic strata are essentially distributed in small sub-basins along the Altyn Tagh and the southern flank of the Qilian Shan in the NE Qaidam basin (Cheng et al., 2019d; Wu et al., 2011).

On the contrary, the Cenozoic strata are widely distributed throughout the basin with their main deposition center systematically located at the geometric center of the basin (Fig. 2) (Meng and Fang, 2008; Xia et al., 2001). According to the lithology and stratigraphy, the Cenozoic strata are classically subdivided into eight lithostratigraphic units, namely the Lulehe (Fm.), $\mathrm{E}_{1+2} \mathrm{l}$; (2) the Lower Xiaganchaigou Fm., $\mathrm{E}_{3}{ }^{1} \mathrm{xg}$; (3) the Upper Xiaganchaigou Fm., $\mathrm{E}_{3}{ }^{2} \mathrm{xg}$; (4) the Shangganchaigou Fm., $\mathrm{N}_{1}$ sg; (5) the Xiayoushashan Fm., $\mathrm{N}_{2}{ }^{1} \mathrm{xy}$; (6) the Shangyoushashan Fm., $\mathrm{N}_{2}{ }^{2}$ sy; (7) the Shizigou Fm., $\mathrm{N}_{2}{ }^{3}$ s; and (8) the Qigequan Fm. $\left(\mathrm{Q}_{1} \mathrm{q}\right)$. Integrating our own basin-scale field investigations and drill core observations with a compilation of previously published data (Fig. 4a-i), we propose a series of depositional environment maps and summarize the sedimentary features of these eight formations (Figure. S1 in the Supplementary materials). The depositional ages for the Cenozoic strata are discussed in Section 4 (Fig. 5).

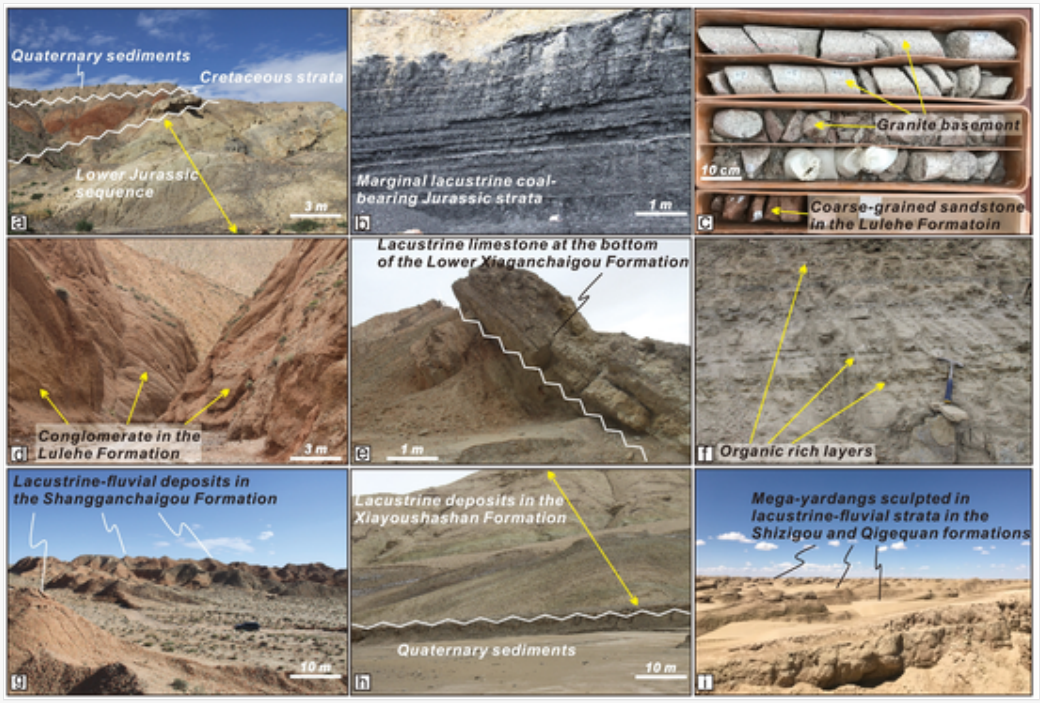

The Mesozoic and Cenozoic strata are cut by a series of NW- to WNW- trending faults also involving the basement ( Fig. 2b-c) that must have participated in accommodating a significant amount of the Cenozoic crustal deformation in the northern Tibetan plateau (Cheng et al., 2014; Cheng et al., 2015c; Meng and Fang, 2008; Sun, 2019; Wang et al., 2010c; Wei et al., 2016; Wu et al., 2019c; Wu et al., 2014; Yin et al., 2008a; Yin et al., 2008b; Yin et al., 2007; Zhou et al., 2006). However, the geometry and kinematics of these faults have long remained debated (Burchfiel et al., 1989; Cheng et al., 2014; Huang et al., 2020; Métivier et al., 1998; Sun, 2019; Yin et al., 2007; Zuza and Yin, 2016), and will be discussed in Section 5.1.

\section{3 Approaches}

\subsubsection{Age model}

To evaluate the age model for the Cenozoic strata in the Qaidam basin, we first review the dating history and explain the details of the two above-mentioned debated age models, including their advantages and limitations (Fig. 5). We also select two seismic profiles in the southern and western parts of the basin that intersect the boundary faults (Fig. 6). After 
superimposing the two age models to the growth strata on these seismic profiles, we compare the obtained deformation histories in the basin with the uplift and exhumation history of the mountain belts as inferred by existing lowtemperature thermochronology data. We then discuss which age model provides a better match. A comprehensive analysis of the age model (Fig. 7) and a future perspective on the age model for the Cenozoic strata in the Qaidam basin are provided.

alt-text: Fig. 6

\section{Figure 6.Fig. $\underline{6}$}

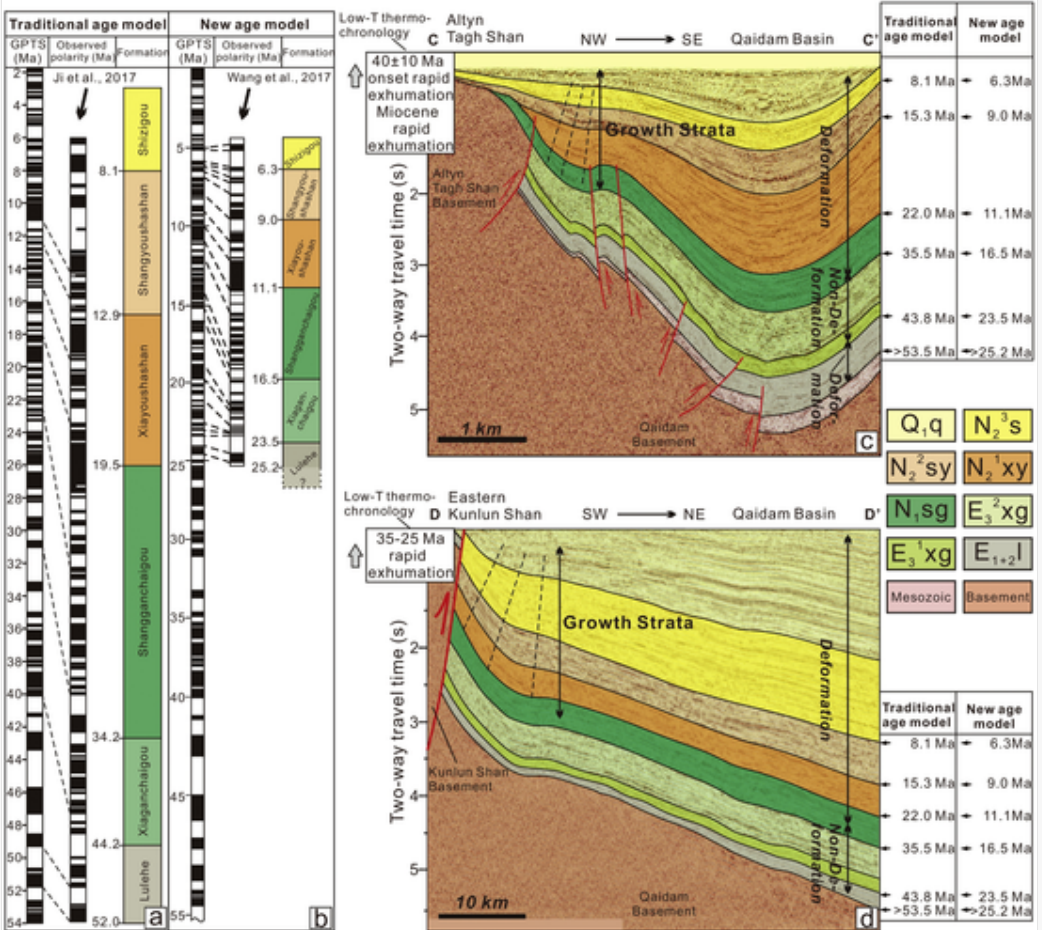

Traditional (a) and new (b) age model for the Cenozoic strata in the Qaidam basin, represented by the work by Ji et al. (2017) and Wang et al. (2017b). Interpreted seismic profiles in the western (c) and southern (d) Qaidam basin. The section CC' is perpendicular to the strike of the Altyn Tagh Shan (Cheng et al., 2016b) while section DD' is perpendicular to the strike of the Eastern Kunlun Shan ( Cheng et al., 2018). The onset time of exhumation in the Altyn Tagh Shan and Eastern Kunlun Shan is from previous low-temperature thermochronology studies (Clark et al., 2010; Jolivet et al., 2001; Wang et al., 2017a; Wang et al., 2015; Zhang et al., 2012). When following the "young ages" model (Wang et al., 2017b), the estimated onset time of deformation indicated by the growth strata conflicts with the onset time derived from the thermochronology data. When following the "old ages" model (Chang et al., 2012; Chang et al., 2015; Fang et al., 2007; Heermance et al., 2013; Ji et al., 2017; Ke et al., 2013; Lu and Xiong, 2009; Sun et al., 2005; Zhang, 2007; Zhang et al., 2013b), the estimated onset time of deformation indicated by the growth strata is consistent with the onset time derived from the thermochronology data. The location of each section is shown in Fig. 2a.

alt-text: Fig. 7

Figure 7.Fig. 7 


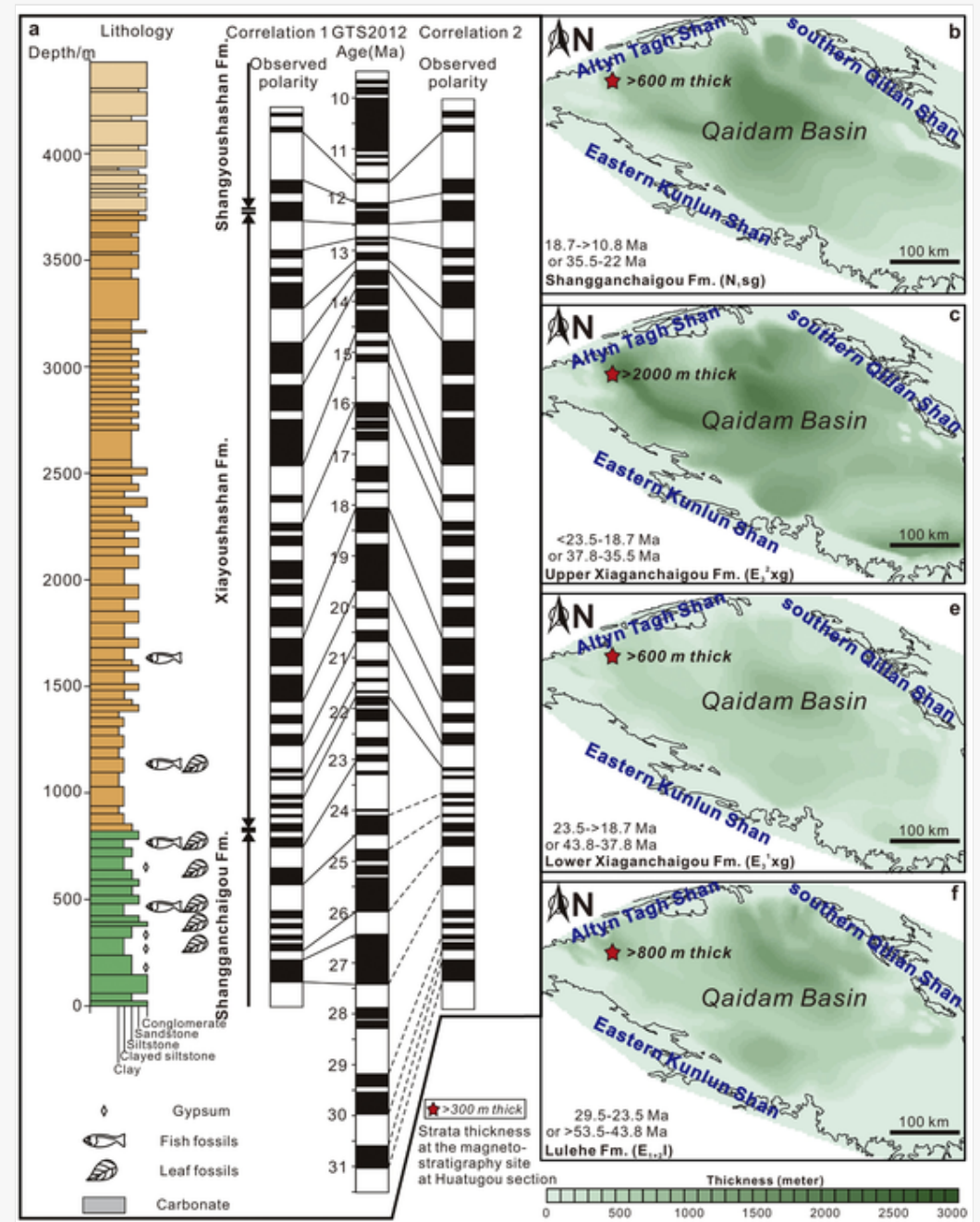

(a) Stratigraphic column and age model for the Cenozoic strata based on a magnetostratigraphy study in the western Qaidam basin, modified from Chang et al. (2015). Isopach map for the Cenozoic strata shows the thickness of the Shangganchaigou Fm. (b), Upper Xiaganchaigou Fm. (c), Lower Xiaganchaigou Fm. (d), and Lulehe Fm. (e) at this magnetostratigraphy site, respectively. Isopach data are from Cheng et al. (2018).

\subsubsection{Interactions between the Qadaim basin and the Eastern Kunlun Shan}

To understand the interactions between the Eastern Kunlun Shan and the Qaidam basin, two fundamental questions should be addressed: 1) What are the structural and kinematic relations between the Qaidam basin and the Eastern Kunlun Shan? (Fig. 8) and 2) What about the physiography of the northern Tibetan plateau margin in the Early Cenozoic? In other words, were the Qaidam and Hoh Xil basins part of a large Paleo-Qaidam basin or were they separated by a proto-Kunlun relief? To answer the first question, we first summarize the current debates on the fault geometry in the SW Qaidam basin. We then use seismic profiles (Figs. 9-11) and isopach data (Fig. 10) to document the structural evolution of the transition zone between the Qaidam basin and the Eastern Kunlun Shan. To answer the second question (Fig. 12), we analyze evidence provided by flexural modeling, sedimentary record (e.g., bulk petrology, detrital zircon geochronology) and subsurface data (seismic profiles, drill core samples, isopach maps) (Figs. 14-17) to document in details the source to sink relation between the Qaidam basin and the Eastern Kunlun Shan. Using the above-mentioned discussion as a guide, we propose a holistic view of the Cenozoic evolution of the basin.

alt-text: Fig. 8

Figure 8.Fig. 8 


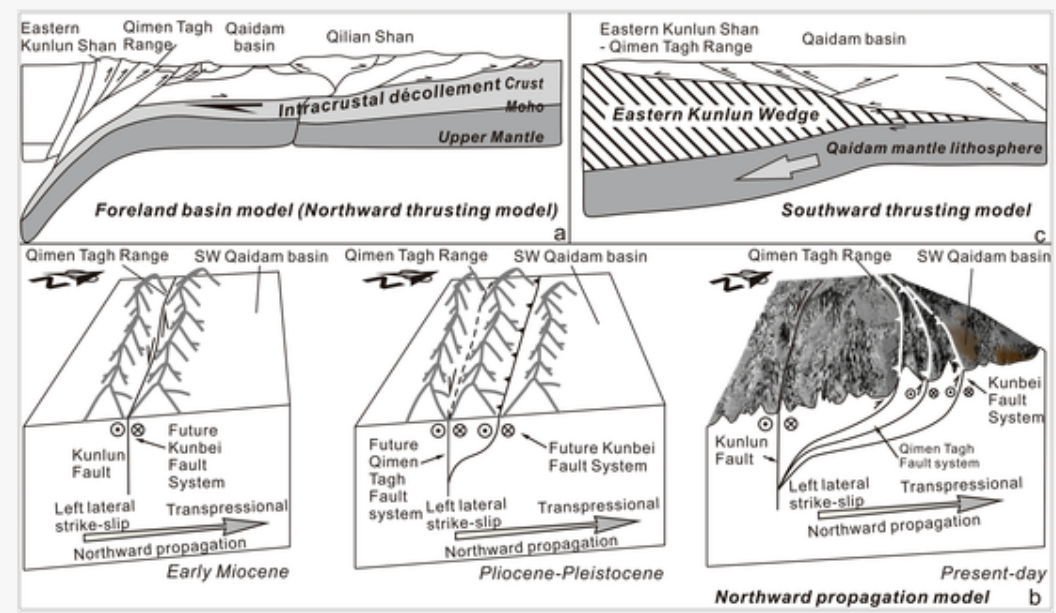

Three typical models to describe the tectonic relation between the Qaidam basin and the Eastern Kunlun Shan. (a) Foreland basin model (northwards thrusting model)(Burchfiel et al., 1989). (b) Southwards thrusting model (Yin et al., 2008b; Yin et al., 2007). (c) Northward propagation model (Cheng et al., 2014).

alt-text: Fig. 9

Figme-Fig. 9 


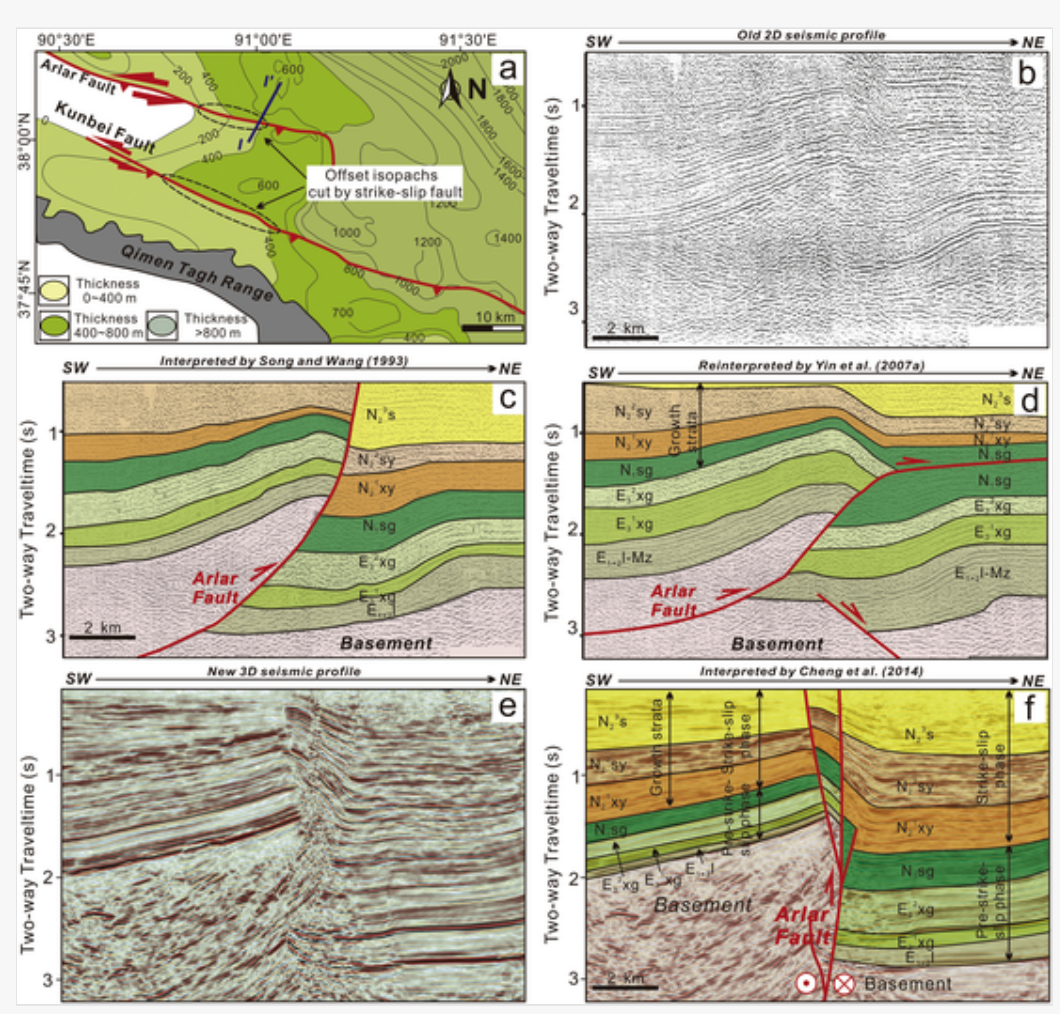

(a) Isopach of the Upper Xiaganchaigou Fm., showing the Kunlun fault and Arlar fault (Cheng et al., 2014). The location of isopach map is shown in Fig. 9a. (b) 2D seismic profile of Song and Wang (1993), across the Arlar fault. (c) interpreted seismic profile by Song and Wang (1993). (d) Interpreted seismic profile by Yin et al. (2007). Uninterpreted (e) and interpreted (f) 3D seismic profile of across the Arlar fault (Cheng et al., 2014). Note that 3D seismic profiles show more obvious reflectors and flower structures are evidenced, indicating strike-slip faulting.

alt-text: Fig. 11

Figure 11,Fig. 11

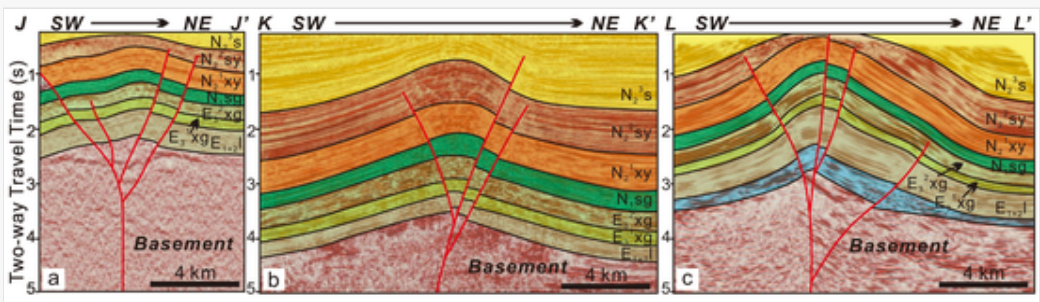

Reinterpreted seismic profiles in the western Qaidam basin. Location of each profile is shown in Fig. 9a. Original profiles are listed in Liu et al. (2019). Note the flower structures, indicating the strike-slip components along these basement-involved faults. $\mathrm{E}_{1+2} 1$; $\mathrm{E}_{3}{ }^{1} \mathrm{xg} ; \mathrm{E}_{3}{ }^{2} \mathrm{xg} ; \mathrm{N}_{1} \mathrm{sg}, \mathrm{N}_{2}{ }^{1} \mathrm{xy}, \mathrm{N}_{2}{ }^{2} \mathrm{sy}, \mathrm{N}_{2}{ }^{3} \mathrm{~s}, \mathrm{Q}_{1} \mathrm{q}$ are the abbreviated symbols for the Lulehe Fm., Lower Xiaganchaigou Fm., Upper Xiaganchaigou Fm., Shangganchaigou Fm., Xiayoushashan Fm., Shangyoushashan Fm., Shizigou Fm., Qigequan Fm., respectively.

alt-text: Fig. 12

Figure 12.Fig. 12

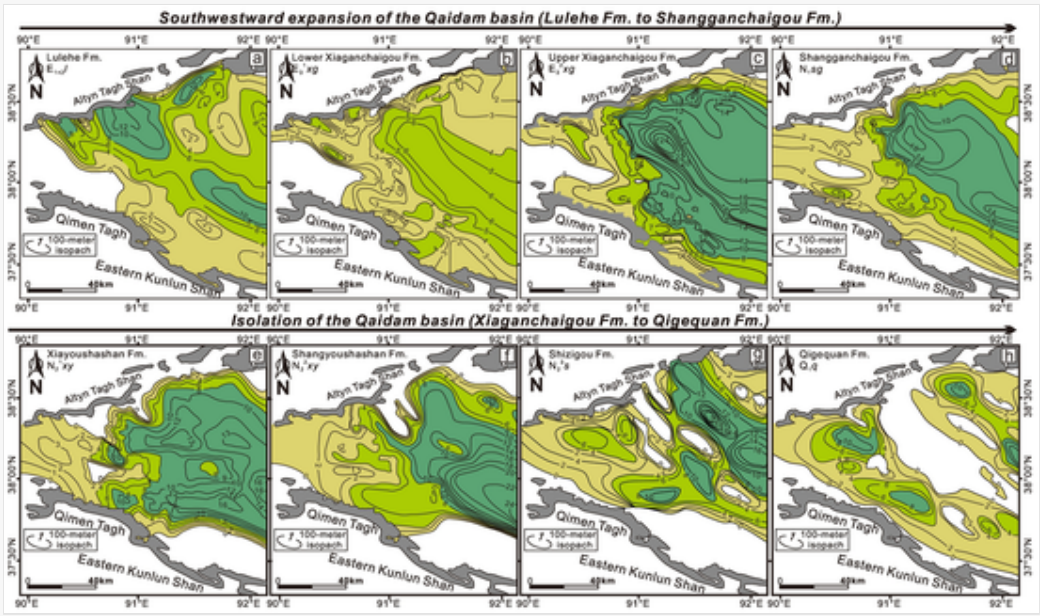




\subsection{Age model of Cenozoic strata in the Qaidam basin}

\subsubsection{Two debated age models}

The first age model established for the Qaidam basin dates back to the late 1980s (Huo, 1990; Yang, 1988). A pioneering magnetostratigraphy study in the western and northeastern parts of the basin was then carried out by Yang et al. (1992), resulting in the following chrono-stratigraphic sequence: Paleocene to Early Eocene_=_Lulehe Fm., Late Eocene_=_Lower and Upper Xiaganchaigou Fms., Oligocene_=_Shangganchaigou Fm., Early to Middle Miocene_=_Xiayoushashan Fm., Middle to Late Miocene_=_Shangyoushashan Fm., Late Miocene to Pliocene_=_Shizigou Fm. Since then, a number of magnetostratigraphy studies have been conducted on the sparse exposures of Cenozoic strata of the Qaidam basin, leading to several different age models (Chang et al., 2012; Chang et al., 2015; Fang et al., 2006; Fang et al., 2007; Heermance et al., 2013; Ji et al., 2017; Ke et al., 2013; Lu and Xiong, 2009; Sun et al., 1999; Sun et al., 2005; Wang et al., 2017b; Zhang, 2007). Despite minor uncertainties in the absolute age of the boundaries between adjacent stratigraphic units, those models generally follow the model initially proposed by Yang et al. (1992) (Figs. 5-6). This stratigraphic framework, to some extent, is supported by the age controls from vertebrate fossils, ostracods, spore and pollen assemblages, fission-track and ${ }^{40} \mathrm{Ar} /{ }^{39} \mathrm{Ar}$ dating of detrital grains as well as regional lithostratigraphic correlations (Chang et al., 2015; Fang et al., 2019; Fang et al., 2006; Fang et al., 2007; Ji et al., 2017; Ke et al., 2013; Lu and Xiong, 2009; Rieser et al., 2006a; Rieser et al., 2006b; Sun et al., 1999; Sun et al., 2005; Yang et al., 1992; Zhang, 2007).

On the other hand, as mentioned above, some recent publications reassigned the depositional age of the Cenozoic strata based on new magnetostratigraphy studies in the Honggou section (northeastern Qaidam basin) (Figs. 2 and 6b). This new age model claims for an Oligocene initial deposition of the Cenozoic strata, and proposes the following chronostratigraphic sequence: Oligocene_=_Lulehe Fm., Early Miocene_=_Lower and Upper Xiaganchaigou Fms., Middle Miocene $=$ =Xiaganchaigou Fm., Late Miocene_=_Shangyoushashan, and Shizigou Fms. (Fig. 5). Unlike the traditional age model, this new age model correlates their observed normal and reversed polarity zones at the Lulehe Fm. to the Late Oligocene to Early Miocene polarity zones at the Geomagnetic Polarity Time Scale (GPTS) (Fig. 6b). This new correlation is mainly based on: 1) Miocene vertebrate fossils found in the upper part of the section; 2) well-preserved and continuous strata without any unconformity or hiatus; 3 ) integrated detrital apatite fission track and detrital zircon geochronology data describing the source to sink relationships between the northeastern part of the Qaidam basin and the surrounding mountain belts; 4) a better match between the mean annual paleoprecipitation record in the Qaidam basin (Nie et al., 2019) and in the Chinese Loess Plateau (Nie et al., 2017) during the mid-Miocene climatic optimum (MMCO, 17-=14.5 Ma) (Zachos et al., 2001).

However, some $20 \mathrm{~km}$ away from the Honggou section, in a laterally well connected section, Ji et al. (2017) performed a second magnetostratigraphic study, relying on biostratigraphic constraints, including palynological assemblages throughout the section, fossil leaves in the lower part of the section, ostracod assemblages, vertebrate fossils and detrital geochronology age constraints in the upper part of the section. Their results assign a Paleocene to Eocene depositional age for the basal part of the Lulehe Fm, completely different from the assignment by Wang et al. (2017b) and Nie et al. (2019), but consistent with the initial correlation of Yang et al. (1992). Given that these two sections are laterally connected and are situated on the same side of a fold in the NE Qaidam basin, these age models cannot be simultaneously correct.

\subsubsection{Which age model is valid and can be better applied to other parts of the basin?}

Both age models provide robust independent vertebrate fossil record at $\sim 12-=14 \mathrm{Ma}$ as biostratigraphic age controls, suggesting convergence of the models for the post-middle Miocene strata and leaving open the debate on the premiddle Miocene strata. Although fossils leaves were identified in the lower part of the section investigated by Ji et al. (2017), these leaves are not index fossils and thus cannot provide a tight age control. A lack of independent age constraints for the lower part of the Honggou section also makes the new age model debatable. Only by exclusively considering the correlation between the observed polarities zones and GPTS, the younger age model seems to provide a better match (Fig. 6b) further reinforced by the higher quality of the data with less gaps in the polarities correlations ( Nie et al., 2019; Wang et al., 2017b).

However, we should still be cautious to assign a Late Oligocene age to the basal Cenozoic strata across the Qaidam basin. As shown on the seismic profiles (Fig. 9), the tectonic framework along the northwestern margin of the Qaidam basin is characterized by complex structures in the fold-thrust belt (Cheng et al., 2019c; Cheng et al., 2019d; Yin et al., 2008a; Yin et al., 2008b). Outcrops in the eastern part of the basin, especially along the southwestern front of the Qilian Shan usually contain much more complex lithostratigraphic units comparing with those exposed in the other parts of the basin (Fig. 2a). If the lithostratigraphic unit at the bottom of this section is truly the Lulehe Fm., it is worthy to carefully 
recheck for potential unconformities, hiatus or faulted contacts along this section. More importantly, previous thermochronology studies have revealed an obvious Paleocene to Early Eocene tectono-thermal event in mountain belts

Q9 surrounding the Qaidam basin (Chen et al., 2011; He et al., 2017; He et al., 2018; Jolivet et al., 2001; Lin et al., 2015; Pan et al., 2013; Staisch et al., 2020; Wang et al., 2010a; Wang et al., 2017a; Wang et al., 2007; Wang et al., 2015), roughly coincident with or shortly post-dating the onset of India-Asia collision. Therefore, crustal shortening and surface uplift in the northern Tibetan plateau might have already initiated in the Early Cenozoic. Materials eroded from these mountain belts undergoing exhumation would then be transported and finally deposited in the adjacent sedimentary basins. This prediction is supported by the occurrence of the well-dated Paleocene-Eocene strata in the Hoh Xil basin (Lin et al., 2020; Miao et al., 2016; Staisch et al., 2014; Wang et al., 2008) and the Eocene strata in the Yumen basin (Cheng et al., 2019b; Dai et al., 2005; Wang et al., 2016b) and Xorkol basin (Li et al., 2018). As a consequence, even if the new age model is valid for the Honggou section, it is likely that these lithostratigraphic units might not be representative of the initial Cenozoic initial subsidence of the Qaidam basin.

Another way to test these two debated age models is to try to tie them to the independent chronology of deformation events recorded in both the basin and surrounding mountain belts (Fig. 6). To establish that chronology, we used the growth strata developed along the margins of the basin and compared the onset time of deformation evidenced from growth strata with the increase in exhumation rate derived from thermochronology data in the hanging wall of boundary reverse faults in the various ranges. Previous thermochronology studies suggested that the Altyn Tagh Shan experienced a first rapid exhumation during the Eocene ( $40 \pm 10 \mathrm{Ma})$ followed by a renewed, strong exhumation since the Miocene (Jolivet et al., 2001; Wang et al., 2006; Wang et al., 2015; Yu et al., 2019a; Yu et al., 2019b; Zhang et al., 2012). Seismic profiles in the northwest margin of the Qaidam basin display well-developed growth strata in the footwall of major thrust faults (Fig. 6c). When following the "old ages" model (Chang et al., 2012; Chang et al., 2015; Fang et al., 2006; Fang et al., 2007; Heermance et al., 2013; Ji et al., 2017; Ke et al., 2013; Lu and Xiong, 2009; Nie et al., 2019; Sun et al., 2005; Wu, 2011; Zhang, 2007; Zhang et al., 2013b; Zhuang et al., 2011b), the Altyn Tagh Shan would have experienced a first Paleocene to Eocene exhumation followed by a second Oligocene to Miocene exhumation, roughly consistent with the thermochronology studies. However, by following the "young ages" model, seismic profiles would show two exhumation pulses at $\sim 25$ to $24 \mathrm{Ma}$ and 17_ _ $<6.3 \mathrm{Ma}$ separated by a period of tectonic quiescence from $24 \mathrm{Ma}$ to $17 \mathrm{Ma}$. This second scenario does not fit the information provided by available thermochronology data (Fig. 6c). Another set of thermochronology studies suggested that the Southern Qaidam Thrust initiated at 35--25 Ma (Clark et al., 2010; Jolivet et al., 2001; [Instruction: Li et al., 2020 should be changed to Li et al., 2021]Li et al., 2020; Mock et al., 1999; Wang et al., 2017a), associated with the simultaneous exhumation of the Eastern Kunlun Shan basement. Seismic profiles from the southern Qaidam basin show well-developed growth strata in the footwall of the Southern Qaidam Thrust that separates the Eastern Kunlun Shan from the Qaidam basin. When following the "old ages" model, the observed pre-growth strata were deposited from the Paleocene to the Eocene, and the growth strata initiated during the Oligocene. The inference of an Oligocene onset of the Southern Qaidam Thrust activity is consistent with the $\sim 35-25$ Ma onset time of initial activity that has been proposed based on thermochronology data. However, if adopting the "young ages" model, the deposition of the pre-growth strata lasted from ca. 25.2 Ma to 16.5 Ma, and the growth strata initiated at the 16.5 Ma (Fig. 6d). The "young ages" model would thus indicate a middle Miocene initiated faulting along the Southern Qaidam Thrust, conflicting with the $\sim 35=-25 \mathrm{Ma}$ age derived from thermochronology (Fig. 6). Based on the obvious discrepancies described above between the established exhumation history in the mountain ranges surrounding the Qaidam basin and the sequence of events implied by the young age model proposed by Wang et al. (2017b) and Nie et al. (2019), we propose that the latest should not be applied to the northwestern and southern parts of the Qadaim basin.

Moreover, combined magnetostratigraphic data with independent age constraints provided by fossils, Chang et al. (2015) indicates an Oligocene Shangganchaigou Fm., Early to Middle Miocene Xiayoushashan Fm., Middle to Late Miocene Shangyoushashan Fm., respectively (Fig. 7a). According to the isopach map of the Cenozoic strata in the Qaidam basin, the Shangganchaigou Fm. is over $600 \mathrm{~m}$ thick at the Honggou magnetostratigraphy study site (Fig. 7b). Moreover, over $2000 \mathrm{~m}$ thick upper Xiaganchaigou Fm., over 600 thick Lower Xiaganchaigou Fm., and over $800 \mathrm{~m}$ thick Lulehe Fm. are also developed (Fig. 7c-f). Considering these additional $>3000 \mathrm{~m}$ thick underlying the Shangganchaigou Fm., the initial depositional age of the Cenozoic strata in that section should be much older than the Oligocene, unless the sedimentation rate was dramatically higher during that period, which is not reflected by the sediment facies (Fig. S1). In other words, the new age model does not fit the entire sedimentary record in the western part of the Qaidam basin and the classic old age model seems to provide a much better match.

The "old ages" model thus seems to fit reasonably well the deformation history obtained from combining growth-strata observations and thermochronology data in the northern and southern Qaidam basin. However, when this issue is examined in more detail, it is likely that the Cenozoic lithostratigraphic units in the Qaidam basin are diachronous from one section to the other and have no basin-wide chronostratigraphic significance. A good example of such diachronicity in foreland deposits is given by the Xiyu Fm. in the Tarim and Junggar basins (Fig. 1). Indeed, these alluvial fans once considered to be synchronous and dated as Early Pleistocene in age (Chen et al., 1994; Feng and Dai, 2004; Gaboardi et al., 2005; Zhu et al., 2004), were later demonstrated to be largely diachronous, spanning at least 
from 15 Ma to $1.7 \mathrm{Ma}$ (Charreau et al., 2009a; Charreau et al., 2005; Charreau et al., 2009b; Cheng et al., 2018;

Heermance et al., 2007; Huang et al., 2010; Sun et al., 2009; Sun et al., 2007).

\subsubsection{Future perspective}

As shown above, the Cenozoic strata preserved in the Qaidam basin record the Cenozoic deformation history of the northern margin of the Tibetan plateau (Meng and Fang, 2008; Métivier et al., 1998; Meyer et al., 1998; Xia et al., 2001; Yin et al., 2008a; Yin et al., 2008b; Yin et al., 2002). In particular, the Lulehe Fm., marking the onset of Cenozoic deposition in the basin, clearly corresponds to the onset of topographic growth of the surrounding mountain belts (Cheng et al., 2019a; Wang et al., 2017b; Xia et al., 2001; Yin et al., 2008a; Yin et al., 2008b; Yin et al., 2007; Yin et al., 2002). The uncertainties in the depositional age of this key formation have major consequences on our understanding of the initial deformation pattern along the northern edge of the plateau. On a larger scale, it also affects our understanding of the mechanisms of crustal deformation in the entire plateau, and finally of the possible interaction between plateau growth and climate change (Bush et al., 2016; Cheng et al., 2019a; Cheng et al., 2019c; Dupont-Nivet et al., 2008; Fu et al., 2012; Wang et al., 2017b; Zhang et al., 2013a). Given the importance of constraining the age model of the Cenozoic strata within the Qaidam basin, increased investigations are thus urgently needed.

First, as pre-Quaternary strata are largely covered by younger deposits in the western Qaidam basin, magnetostratigraphy study could be carried out on the deep drilling cores obtained by the Qinghai Oilfield Company, PetroChina. Second, a recent detrital zircon geochronology study in the southwestern part of the Qaidam basin reported Cenozoic U-Pb zircon ages (e.g. $37 \mathrm{Ma}$ and $56 \mathrm{Ma}$ ) from the Miocene and Pleistocene strata in the southern part of the basin (Cheng et al., 2016a). This indicates that Early Cenozoic volcanic ash might have been deposited in some parts of the Qaidam basin. Finding and dating those ashes would indeed bring robust constraints to the age model. Third, U-Pb dating of authigenic carbonate minerals from lacustrine strata in nonmarine systems are now widely used to determine the depositional ages (Drost et al., 2018; Finzel and Rosenblume, 2020; Rasbury and Cole, 2009). The well-developed limestones and marls in the Lulehe Fm. to Shangganchaigou Fms. (Chang et al., 2015; Cheng et al., 2019a; Cheng et al., 2019c; Meng and Fang, 2008; Miao et al., 2011; Rieser et al., 2009a; Xia et al., 2001) are suitable materials that hold great potential for determining such depositional ages. Using outcrops and the dense drill core network, a detailed $\mathrm{U}-\mathrm{Pb}$ dating of carbonate samples from the Xiaganghaigou to the Shangganchaigou Fms. across the basin would not only provide independent age controls for the corresponding magnetostratigraphy studies but also bring detailed constraints on the potential diachronicity of the units inside the basin. Fourth, Re-Os geochronometry has been widely used as a proxy for determining precise and accurate depositional ages of marine organic-rich rocks (Rooney et al., 2020; Selby and Creaser, 2003; Tripathy et al., 2015) and is now successfully applied to similar deposits in lacustrine nonmarine systems (Cumming et al., 2012; Cumming et al., 2014; Meng et al., 2020). As the largest petroliferous basin in the Tibetan plateau, the Qaidam basin contains abundant rocks that are rich in organic matter, especially the lacustrine source rocks in the Xiaganchaigou Fm. and Shangganchaigu Fm. (Fu et al., 2015; Jin et al., 2002; Pang et al., 2004). An extensive, basin-wide Re-Os geochronology study would again enhance our understanding of the depositional age of the corresponding Cenozoic strata pointing out potential stratigraphic diachronicity.

Finally, a better understanding of the tectonic and sedimentary interactions between the Qaidam basin and the surrounding belts would contribute to a better knowledge of the basin fill history, which, in turn, would help assessing the degree of reliability of the age model proposed through the above-mentioned geochronometer. Although datasets on the sedimentation and deformation history of the Tibetan plateau (e.g., low- and high- temperature geochronology, provenance data, isotopic data, palynology, seismic profiles) have improved significantly over the last few decades, the understanding of the interaction between the Qaidam basin and the surrounding belts is still hampered by the incomplete coverage of these datasets, especially from remote and often inaccessible regions (Wu et al., 2019a; Yin et al., 2007).

\subsection{Interactions between the Eastern Kunlun Shan and the Qaidam basin}

\subsubsection{Tectonic relation between the Qaidam basin and the Eastern Kunlun Shan}

\subsection{South-dipping vs north dipping boundary fault in the southern Qaidam basin}

The debate on the upper crustal structural relation between the Eastern Kunlun Shan and the Qaidam basin has become particularly heated during the last two decades. Although several models have been proposed (Burchfiel et al., 1989; Cheng et al., 2014; Huang et al., 2020; Jolivet et al., 2003; Meng and Fang, 2008; Meyer et al., 1998; Mock et al., 1999; Tapponnier et al., 2001; Wang et al., 2006; Xia et al., 2001; Yin et al., 2007), three typical models (Fig. 8) that describe the tectonic structure in the Eastern Kunlun Shan and in the SW Qaidam basin are representative of the key questions that remain debated: (1) Northward thrusting model, (2) Northward propagation model, (3) Southward thrusting model.

First, the northward thrusting model dates back to the 1980s. Burchfiel et al. (1989) proposed that the Qaidam basin is bounded to the south by a south-dipping fault. North-directed motion of the southern block would induce thrusting of the Eastern Kunlun Shan crust onto the Qaidam basin leading to the uplift of the Eastern Kunlun Shan (Fig. 8a). 
Following this model, Mock et al. (1999) further argued that, from the Oligocene to the Early Miocene, this northdirected thrusting would be associated with the formation of a crustal wedge in the Eastern Kunlun Shan. Therefore, this model considers the southwestern part of the Qaidam basin as a foreland basin of the Eastern Kunlun Shan. Meng and Fang (2008) proposed that the Cenozoic tectonic subsidence of the Qaidam basin may result from crustal buckling in response to regional NE-trending compression. In this model, north-directed thrusting, initiating during the Miocene along the south-dipping boundary fault, may have controlled the exhumation of the Qimen Tagh Range, the western segment of the Eastern Kunlun Shan (Fig. 2) (Cheng et al., 2014). The second type of models emphasizes the role of sinistral strike-slip faults in the Eastern Kunlun Shan. The structural pattern of the range would be characterized by a large transpressional system, including the left-lateral strike-slip Kunlun fault to the south and a series of south-dipping thrusts to the north (Jolivet et al., 2003; Meyer et al., 1998; Tapponnier et al., 2001; Wang et al., 2006). Cheng et al. (2014) further developed this model and proposed a northward propagation model (Fig. 8b). This model emphasizes the Neogene northward bending and propagation of the fault system initiating as strike-slip lineaments along the Kunlun fault and progressively switching to thrusts, forming a northward growing crustal wedge (Fig. 8b). In the meantime, Yin et al. (2007) proposed a quite different model arguing that several south-directed thrusts rooted into the Qilian Shan to the north propagated southward, carrying the low-elevation Qaidam basin to the high-elevation Eastern Kunlun Shan (Fig. 8c). This southward thrusting model has been adopted by some recent studies (Shi et al., 2009; Wang et al., 2011; Wu et al., 2019b; Zuza and Yin, 2016), attracting a growing attention from the Asian tectonics community in recent years.

The abundant, high quality subsurface data acquired by the oil industry in recent years enable a re-evaluation of these three competing models. First, isopach maps show that the Cenozoic strata (including the Lulehe, Lower and Upper Xiaganchaigou, and Shangganchaigou formations) generally thicken from the southern margin of the basin towardstoward its center (Figs. 2b-c, 12) (Cheng et al., 2018; Mao et al., 2014a; Meng and Fang, 2008; Yin et al., 2008b). This pattern opposes the classic tectonically subsiding foreland-basin model that requires the depocenter to be situated next to the bounding fault (Jordan, 1981). To this end, the foreland basin model (northwards thrusting of the Eastern Kunlun Shan) (Burchfiel et al., 1989; Mock et al., 1999) does not seem to explain the structural relation between the Eastern Kunlun Shan and the Qaidam basin.

On the other hand, the south-directed thrusting model put forward by Yin et al. (2007) was mainly based on: 1) observation of an unconformity between the north-dipping Pliocene-Quaternary strata and the Ordovician to Carboniferous strata of the Eastern Kunlun Shan; 2) evidence for south-directed thrusting in the Carboniferous strata; 3) observation, on 2D seismic profiles, of several south-directed reverse faults beneath the southwestern part of Qaidam basin; 4) the reporting of several north-dipping faults in the Eastern Kunlun Shan on existing geological map (Liu, 1988) and in fieldwork reports of (Dewey et al., 1988). We acknowledge the importance of the observed unconformity between the Pliocene-Quaternary strata and the Ordovician to Carboniferous basement rocks of the Eastern Kunlun Shan. Yet this observation may just indicate the exhumation of the Eastern Kunlun Shan during or before the deposition of Pliocene-Quaternary strata. The geological map by Liu (1988) is 1: 1,500,000 scale and cannot display subtle key information on faults geometry, whereas the field investigation performed by Dewey et al. (1988) is limited to a narrow strip along the Golmud to Lhasa road, covering only a small portion of the Eastern Kunlun Shan near the Golmud ( Kidd et al., 1988). More recent geological maps (1: 250,000 scale) report several major north-directed thrust faults in the Qimen Tagh Range, forming the western part of the Eastern Kunlun Shan (I.G.S.Q.P, 2004; I.G.S.S.P, 2003). These faults might support the northward thrusting model, contradicting the southward thrusting hypothesis. More importantly, several newly acquired 2D and 3D high-quality seismic profiles display series of south-dipping faults beneath the southwestern part of Qaidam basin (Fig. 9b-c). On NE-trending seismic profiles EE' and FF', these thrusts are high angle basement-involved faults defining a block-like structure (Fig. 9b). These faults cut the Cenozoic sediments rooting into the Eastern Kunlun Shan and Qaidam basement. On seismic profile EE', the thickness of the Lower Cenozoic lithostratigraphic units (Lulehe Fm. to Xiaganchaigou Fm.) in the footwall do not match with those of the hanging wall. The post-Xiaganchaigou Fm. strata taper toward the faults, forming growth strata (Fig. 9c). On seismic profile FF', the post-Xiaganchaigou Fm. in the SW Qaidam basin again taper toward the faults, forming growth strata that indicate the onset of deformation accommodated along these faults (Fig. 9c). Based on a 2D low-resolution seismic profile (Fig. 10a-b), Song and Wang (1993) suggested that the Arlar fault cuts through all the Cenozoic strata up to earth surface. They interpreted such fault as a long-lived purely reverse fault that initiated during the Early Cenozoic (Fig. 10c). However, Yin et al. (2007) reinterpreted the same 2D seismic profile by describing a fault-bend fold above the Arlar fault. In that second model, this basement-involved fault cuts through the Mesozoic to Early Cenozoic strata (Lulehe, Lower and Upper Xiaganchaigou Fms.) and forms a footwall flat within the Shangganchaigoou Fm. (Fig. 10d). The growth strata started to develop during the deposition of the Shangganchaigou Fm. suggesting that the Arlar fault initiated at this time. Finally, based on a newly acquired much higher resolution 3D seismic profile from the same location (Fig. 10e), Cheng et al. (2014) proposed that the Arlar fault is characterized by a positive flower structure, indicating strike-slip displacement along the fault (Fig. 10f). The isopachs of the Upper Xiaganchaigou Fm. show over $20 \mathrm{~km}$ lateral offset across the Arlar and Kunbei faults (Fig. 10a), indicating sinistral strike-slip movements along these two faults. Growth strata associated with the flower structure initiated during the deposition of the Xiayoushashan Fm., probably dating the onset time of left-lateral faulting along the Arlar fault (Fig. 
10f). We thus propose that left-lateral faulting along these structures (including the Arlar and Kunbei faults) in the southwestern part of the Qaidam basin initiated during the deposition of the Shangganchaigou Fm. to Xiayoushashan Fm. (Fig. 10). Some of the basement-involved faults within the basin also display a major strike-slip component reflected by flower structures on the seismic profiles (Fig. 11) (Liu et al., 2019). These flower structures reveal transpressional deformation within the basin, indicating that the N-S contraction in the northern Tibetan plateau was slip-partitioned along these WNW-striking faults in the Qaidam basin.

Moreover, isopach maps show that the depocenters of the southwestern part of the Qaidam basin are located next to the Eastern Kunlun Shan during deposition of Xiayoushashan and Shangyoushashan Fms. (Fig. 12e-f), coincident with the Oligocene to Miocene rapid exhumation of the Eastern Kunlun Shan revealed by low-temperature thermochronology (Dai et al., 2013; Duvall et al., 2013; Jolivet et al., 2001; Jolivet et al., 2003; McRivette et al., 2019). As a consequence, the southwestern part of the Qaidam basin might be considered as a foreland/flexural basin of the Eastern Kunlun Shan during deposition of the Xiayoushanshan and Shangyoushashan Fms. In summary, these newly acquired subsurface data allow us to interpret the basement-involved faults as south-directed dipping thrusts, rooting into the Eastern Kunlun Shan (Cheng et al., 2014; Cheng et al., 2015c; Sun, 2019; Wu et al., 2014), ruling out the north-directed thrusting model.

\subsection{The northward propagation model}

The structural pattern discussed above can be summarized as: 1) a series of south-dipping faults control the general tectonic pattern of the southwestern part of the Qaidam basin; 2) these faults have a sinistral strike-slip component accommodated during the deposition of the Shangganchaigou to Xiayoushashan Fms. Based on the evidence of a southwards younging of the onset of sinistral strike-slip motion on the faults from the SW Qaidam basin to the Qimen Tagh Range and to the modern Kunlun fault, Cheng et al. (2014) proposed a northward fault-propagation model. This model considers the faults beneath the southwestern part of the Qaidam basin and the faults within the Qimen Tagh Range as the former western segments of the Kunlun fault. These faults were once located further south in the presentday location of the Kunlun fault and gradually migrated northward since the deposition of the Shangganchaigou to Xiayosuhashan Fm., while their kinematics changed from sinistral strike-slip motion to NE-SW contraction. We believe that the distinctive distribution of Cenozoic strata and the geometry of the faults in the southwestern part of the Qaidam basin can be reconciled with this northward propagation model (Cheng et al., 2014). Indeed, it better explains the kinematics framework by taking the Neogene northward bending and propagation of the successive strike-slip faults into consideration. During the deposition of the Lulehe to Xiaganchaigou Fms., tectonic activity in the Eastern Kunlun Shan and the southwestern part of the Qaidam basin was null or very low. Since the deposition of the Shangganchaigou to Xiayoushashan Fm., the south-dipping basement-evolved faults gradually migrated northward. Their sinistral strike-slip motion gradually changed to the NE-SW contraction which controlled the deposition of the Neogene sediments in the SW Qadaim basin.

\subsection{Uncertainties of fault geometry and further work}

Despite the improvements brought by the newly available geophysical data on our understanding of the structural pattern along the SW margin of the Qaidam basin, it should still be noted that the strong seismic noise in the region adjacent to the mountain ranges prevents clear imaging of that key boundary region (Cheng et al., 2014; Cheng et al., 2015c; Sun, 2019; Wang et al., 2010c; Wu et al., 2014). The interpretation of either a north-directed (Mock et al., 1999; Sun, 2019) or a south-directed décollement (Yin et al., 2007) beneath the Cenozoic strata in the Qaidam basin remains speculative. Analyzing the earthquake focal mechanisms and focal-depth distribution within the Eastern Kunlun Shan, Chen et al. (1999) proposed that the southern Qaidam basin is bounded by a south-dipping thrust fault to the south. However, as Yin et al. (2007) pointed out, projecting the earthquake data collected from over $1000 \mathrm{~km}$ along the Eastern Kunlun Shan on a single cross-section is problematic. Besides, focal mechanisms for reverse or normal faults would have two opposite nodal planes difficult to relate to true faults in the absence of additional field evidence (Yin et al., 2007). Therefore, despite the improvement of the quality of the seismic reflection data in the southwestern part of the Qaidam basin (Cheng et al., 2014; Cheng et al., 2015c; Sun, 2019; Wu et al., 2014) and increased field-based geologic mapping in the remote Eastern Kunlun Shan (Staisch et al., 2020; Wu et al., 2019a), further geological and geophysical work is needed. The researches should especially focus on determining which are the major boundary faults and which are associated back-thrusts.

\subsubsection{Was there a large depression in the northern Tibetan plateau during the Early Cenozoic?}

Besides the structural relation between the Eastern Kunlun Shan and the Qaidam basin, another important issue associated with the Cenozoic evolution of the northern Tibetan plateau is the source to sink relationship between the Eastern Kunlun Shan and the Qaidam basin. As described above, the isopach maps (Fig. 11e-f) indicate that the Neogene (post-Xiayoushashan Fm.) SW Qaidam basin can be described as a foreland basin, a geometry supported by the Miocene rapid exhumation of the Eastern Kunlun Shan (See discussion in Section 5.2.3) as revealed by the lowtemperature thermochronology (Fig. 12) (Dai et al., 2013; Duvall et al., 2013; Jolivet et al., 2001; Jolivet et al., 2003; Mao et al., 2014a; McRivette et al., 2019). However, this geometry does not seem to have prevailed during the Early 
Cenozoic and the occurrence of a Paleogene Paleo-Qaidam basin encompassing the Qaidam and Hoh Xil depressions (

Yin et al., 2008b) remains speculative (Figs. 1a and 13a). This hypothesis is based on similarities in stratigraphic characteristics of the Cenozoic strata in the Qaidam and Hoh Xil basins and the rapid Miocene exhumation of the Eastern Kunlun Shan that would have ultimately separated the two depressions. In this model, the minor depocenter in the southern Qaidam basin during the deposition of Lulehe Fm. was interpreted as a syncline creating a local subdepocenter. If correct, this model suggests no or little paleo-relief in the Eastern Kunlun Shan during the Early Cenozoic and out-of-sequence deformation (i.e., Paleogene deformation in the Qilian Shan to the north with Neogene deformation in the Eastern Kunlun Shan to the south) in the northern Tibetan plateau, which will largely affect our understanding of the growth pattern of the entire Tibetan plateau. The key to answering these questions is whether the Eastern Kunlun Shan was exhumed during the Early Cenozoic. Indeed, several lines of evidence challenge the burial of the Eastern Kunlun Shan during the Early Cenozoic.

\section{alt-text: Fig. 13 \\ Figure 13.Fig. 13}

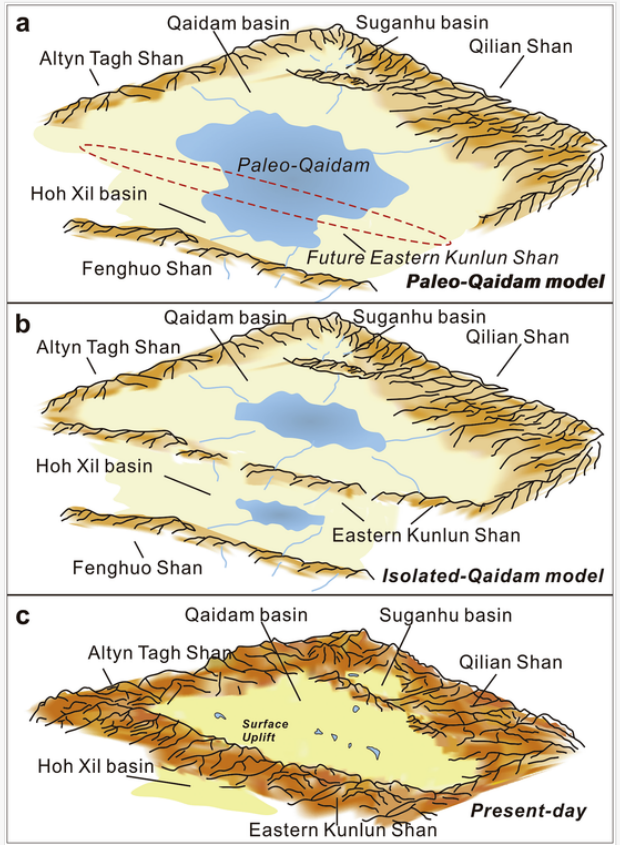

Two scenarios for the evolution of the Qaidam basin and the Eastern Kunlun Shan during the Cenozoic. (a) Paleo-Qaidam model, forming a large depression in the northern Tibetan plateau (Mao et al., 2014a; Yin et al., 2008b). (b) Isolated-Qaidam model, showing the minor topographic relief in the Eastern Kunlun Shan, cutting off the link between the Qaidam basin and the Hoh Xil basin (Cheng et al., 2016a; Cheng et al., 2019c). (c) Modern topography of the Qaidam basin and surrounding regions.

\subsection{Flexural modeling evidence}

Using seismic profiles and isopach maps, Cheng et al. (2019a) reconstructed the original shape of a NE-trending section across the Qaidam basin at the time of deposition of the Lulehe Fm. after conducting the balanced cross-section restoration and decompaction. The authors subsequently modeled the shape of this profile using flexural modeling (Fig. 14). Comparing this model with the restored cross-section, it appears clearly that the topographic load induced by the Qilian Shan alone cannot create a sufficient load to cause the observed deflection of the Qaidam basement during the deposition of the Lulehe Fm. (Fig. 14a). Changing the size (equivalent to the topographic load) of the Eastern Kunlun Shan and Qilian Shan cannot provide a better fit between the modeled deflection of the Qaidam basement and the original shape of the Qaidam basin restored from geological data (Fig. 14b-e). In other words, both the Eastern Kunlun Shan and the Qilian Shan basements should be exhumed during the deposition of the Lulehe Fm., and the associated overload was responsible for the flexural deflection of the Qaidam basement. Following this methods, Wang et al. 
(2021) analyzed four additional NE-trending sections across the Qaidam basin at the time of deposition of the Lulehe Fm. and further documented the variable along-strike relief of the Eastern Kunlun Shan at that time. Based on these information, we thus conclude that, during deposition of the Lulehe Fm., a non-negligible paleo-Kunlun relief was present, separating the SW Qaidam from the Hoh Xil basins.

alt-text: Fig. 14

Figure 14,Fig. 14

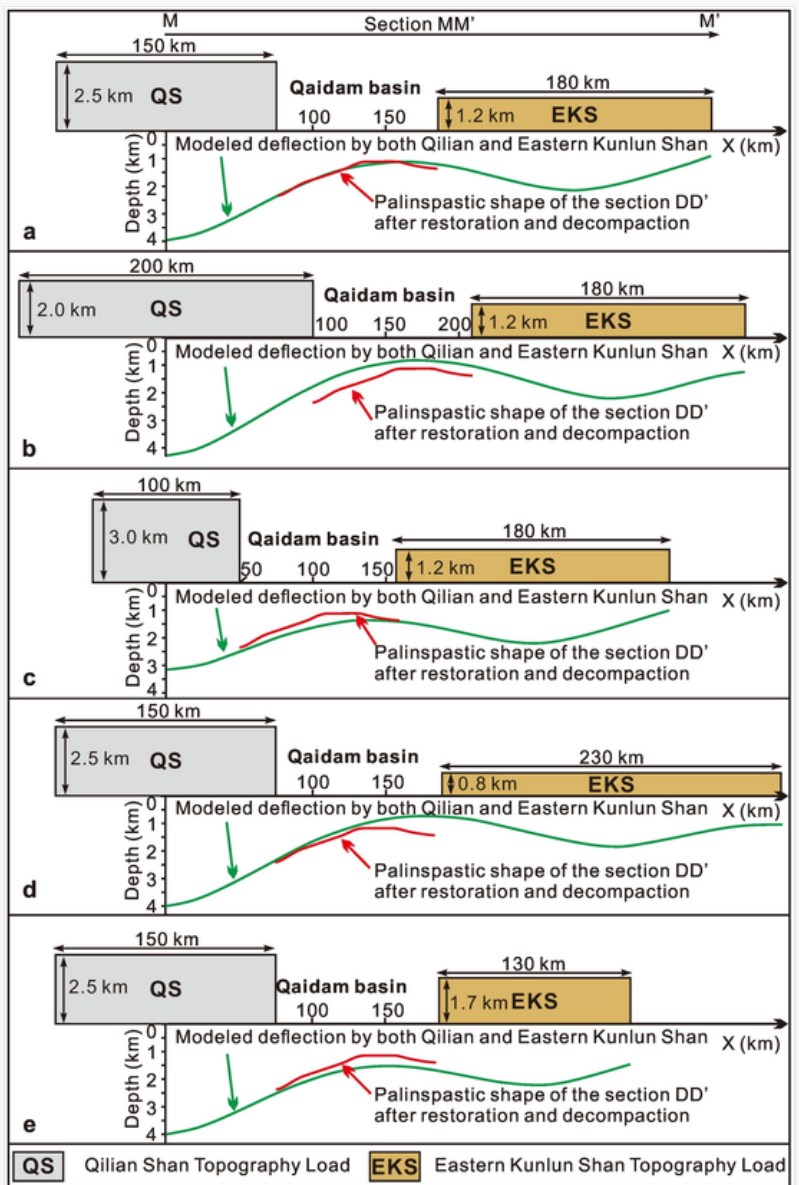

Two-load bean flexural modeling results, showing that both Eastern Kunlun Shan topographic loads are responsible for the flexural of the Qaidam basement, modified from Cheng et al. (2019a). The location of this section MM' is given in Fig. 9a. Note that changing the size of the Eastern Kunlun Shan and Qilian Shan cannot provide a better fit between the modeled deflection of the Qaidam basement (green curve) and the original shape of the Qaidam basin (red curve) that restored after decompaction and the cross-section shortening restoration. See Cheng et al. (2019a) for the detailed flexural modeling experiment._(For interpretation of the references to colour in this figure legend, the reader is referred to the web version of this article.)

\subsection{Sedimentary records}

Based on sediment samples obtained from drill cores in the southern Qaidam basin, the Lulehe Fm. in the southern Qaidam basin is described as boulder-to cobble-sized clast-supported conglomerate (Fu et al., 2012; Gong et al., 2012; Ma and Wang, 2015; Mu, 2002; Sun et al., 2005; Zhang et al., 2013a). However, fine-grained fluvial and lacustrine deposits have also been observed in the Lulehe Fm. in the southwestern part of Qaidam basin, indicating a complex depositional environment pattern (Cheng et al., 2019a; Cheng et al., 2019c). Cheng et al. (2019a) carried out an extensive study based on the core samples obtained from a wide range of drill wells to document the sedimentary characteristics of the Lulehe Fm., indicating both proximal and distal deposits (Fig. 15a-e). Meanwhile, heavy mineral analysis on the Lulehe Fm. core samples collected from the drilling wells along the southern margin of the basin also revealed a dominating zircon-leucoxene-garnet-sphene assemblage. This result indicates that the Lower Paleozoic and Lower Mesozoic igneous rocks in the Qimen Tagh Range were likely the sources of material deposited in the southwestern part of the Qaidam basin (Li et al., 2015a; Zhu et al., 2017). In addition, unstable minerals, such as the epidote, were well-preserved in in those samples. Given that these unstable minerals are unlikely to have been preserved under long-distance transport from the Altyn Tagh Shan or Qilian Shan, the Eastern Kunlun Shan should be the primary source region for the southwestern part of Qaidam basin during that period (Fu et al., 2013; Li et al., 2015a; Zhu et al., 2017). Moreover, Cheng et al. (2016a), reported foraminifera-bearing carbonate fragments are preserved within Lulehe Fm. conglomerates in the SW Qaidam basin (Fig. 15f). Given that foraminifera are generally found in marine environments (Rohling et al., 1998) and carbonate fragments are not transported over long distances (Mack and Rasmussen, 1984; Zuffa, 1980), a simple explanation for these carbonate fragments is that they were derived from the 
alt-text: Fig. 15

Figure 15.Fig. 15

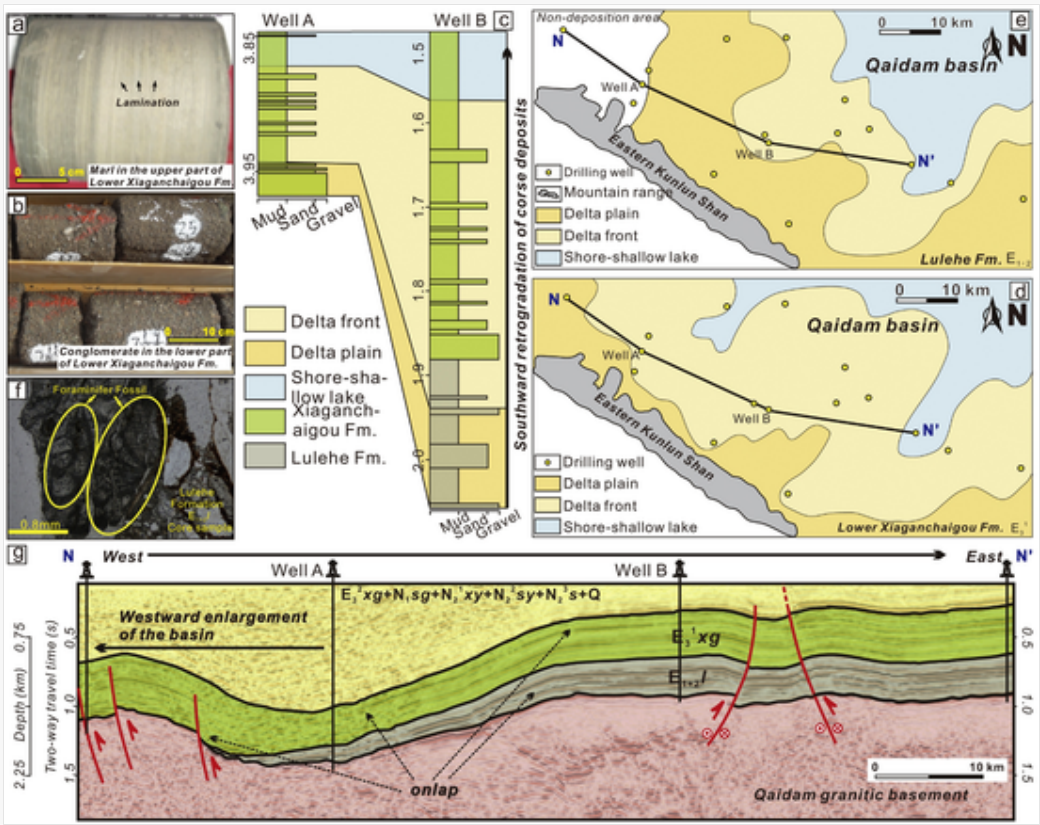

Photographs of the core samples collected from the SW Qaidam basin, showing the laminated marls in the Lower Xiaganchaigou Fm. (a) and the conglomerates in the Lulehe Fm. (Cheng et al., 2019c) (b). (c) Well-correlation diagram of the Lulehe Fm. and Lower Xiaganchaigou Fm. strata based on well-log and drill core data in the SW Qaidam basin. Distribution of facies during the deposition of the Lulehe Fm. (d) and Lower Xiaganchaigou Fm. (e) in the SW Qaidam basin (Cheng et al., 2019c). The location of facies map is shown in Fig. 9a. (f) Plane polarized light microphotograph of core samples collected from the Lulehe Fm. in the SW Qaidam basin, from Cheng et al. (2016a). Note the foraminifera fossils in carbonate debris within conglomerates. (g) Interpreted seismic profile in the SW Qaidam, displaying the successive westward (mountain-ward) onlap of the Lulehe and Lower Xiaganchaigou formations, modified from Cheng et al. (2019c). The location of section is shown in Fig. 9a.

\subsection{Low-temperature thermochronologyl record}

Published low-temperature thermochronology data reveal that the Eastern Kunlun Shan might have experienced a twostage exhumation history during the Cenozoic: (1) Paleocene to Early Oligocene initial exhumation and (2) Late Oligocene to Miocene rapid exhumation. Thermochronology data and modeling in the Eastern Kunlun Shan show initial rapid exhumation as early as ca. 55--40 Ma (Clark et al., 2010; Jolivet et al., 2001; Shi et al., 2018; Staisch et al., 2020; Wang et al., 2017b; Wu et al., 2020). More specifically, apatite and zircon fission track and (U-Th)/He thermochronology studies on the crystalline rocks of the Eastern Kunlun Shan revealed that the exhumation of the Eastern Kunlun Shan might have initiated at $40 \pm 10 \mathrm{Ma}$ in response to the India-Asia collision (Clark et al., 2010; Jolivet et al., 2001; Staisch et al., 2020; Wang et al., 2017b). Meanwhile, (U-Th)/He thermochronology studies on detrital apatite from upper Eocene to Pliocene strata within the Eastern Kunlun Shan indicated that high mountain ranges in the Eastern Kunlun Shan might have formed at or before $40 \mathrm{Ma}$ (Shi et al., 2018). On the other hand, the rapid exhumation of the Eastern Kunlun Shan during the Oligocene to Miocene has been inferred by a number of lowtemperature thermochronology studies (Dai et al., 2013; Duvall et al., 2013; Jolivet et al., 2001; Li et al., 2021; Liu et al., 2017; McRivette et al., 2019; Staisch et al., 2020; Wang et al., 2018; Wu et al., 2020; Yuan et al., 2003).

Although it is obvious that a Paleogene relief existed in the Kunlun region, it is also undeniable that strong similarities existed between the sediment facies in both basins (Yin et al., 2008b). Following that observation, the question whether the two basins were completely disconnected or not still remains open. On seismic profile MM' (Fig. 15g), the successive westward onlaps of the Lulehe and Lower Xiaganchaigou Fm. suggest a mountainward expansion of the Qaidam basin during the Paleocene - Early Eocene. This inference of a progressive expansion of the drainage area in the SW Qaidam basin is further supported by the progressively westward retrogradation of the fluvial-deltaic deposits ( Fig. 15e-d) and by the westward expansion of the Lulehe to Shangganchaigou deposits (Fig. 12a-d). Moreover, the increasing proportion of Mesozoic to Late Paleozoic and Precambrian U-Pb detrital zircon ages in samples from the Lulehe Fm. to the Shangganchaigou Fm. further suggest a widening of the source regions, again supporting the expansion of the drainage system in the SW Qaidam basin (Fig. 16). These observations thus suggest that while some relief existed in the Eastern Kunlun Shan area during the Paleogene, the Qaidam basin drainage area nonetheless might have expanded progressively during that period, likely merging with that of the Hoh Xil basin to the south (Fig. 13b). This connection was cut off during the Miocene due to the rapid exhumation of the Eastern Kunlun Shan. This 
inference of a Late Oligocene to Miocene isolation of the Qaidam basin is consistent with the reduction of the deposition area observed on the isopach maps (Fig. 12e-h).

\section{alt-text: Fig. 16 \\ Figure 16.Fig. 16}

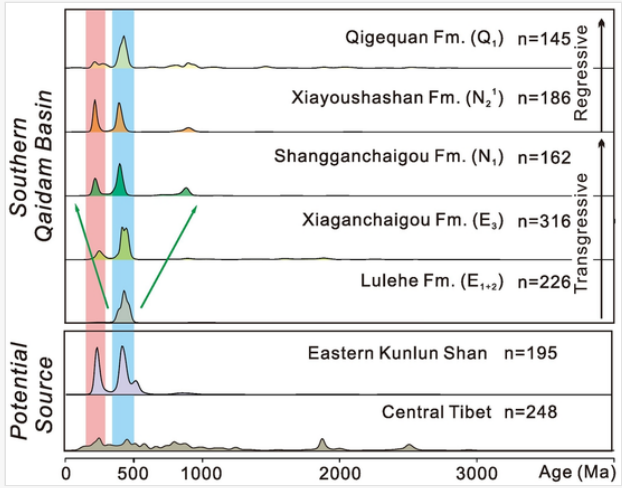

Detrital zircon age spectra for Cenozoic sandstone samples from the SW Qaidam basin and relative probability plot of granitoid pluton ages in the Eastern Kunlun Shan and the Central Tibet. Zircon ages from the Cenozoic sandstone and basement rocks of potential source regions are mainly compiled from (Cheng et al., 2016a; Cheng et al., 2017; Dai et al., 2012). The green arrows show that the distribution of the zircon ages becomes more diverse from the Lulehe Fm. sample to the Shangganchaigou Fm., probably indicate the expansion of the drainage are of the Qaidam basin._(For interpretation of the references to colour in this figure legend, the reader is referred to the web version of this article.

In summary, flexural modeling, sedimentology and low-temperature thermochronology evidence demonstrate that no single large depression developed during the Paleocene and that the Eastern Kunlun Shan was exhumed during the Paleocene to Early Oligocene, feeding clastic material to the Qaidam basin. In the same time, the southwestern part of the Qaidam basin drainage area was expanding southward toward the Hoh Xil basin depression implying that the relief in the Eastern Kunlun Shan area was limited. This inference of an existing minor exhumation in the Eastern Kunlun Shan during the Early Cenozoic has been adapted to the tectonic evolution model of the northern Tibetan plateau by McRivette et al. (2019).

\subsection{Implication for the Cenozoic evolution of the Qaidam basin}

Based on the various arguments discussed above, we propose a holistic view of the Cenozoic evolution of the Qaidam basin. Given the debates on the age model for the Cenozoic strata in the Qaidam basin, the lithostratigraphic units are used to describe the corresponding time period without reference to an absolute time-scale. We propose a three-stages evolution model including: 1) initial flexural subsidence; 2) basin-scale expansion; 3) isolation.

\subsubsection{Flexural subsidence of the Qaidam basin}

Thermochronology studies (e.g., ${ }^{40} \mathrm{Ar} /{ }^{39} \mathrm{Ar}$ dating and apatite fission track) have revealed several Mesozoic tectonothermal events in the Altyn Tagh Shan, Eastern Kunlun Shan, and Qilian Shan, indicating substantial crustal deformation in the northern Tibetan plateau during the Mesozoic (Arnaud et al., 2003; Baotian et al., 2013; Chen et al., 2003; Chen et al., 2009; Cheng et al., 2016c; Dai et al., 2013; Du et al., 2018; He et al., 2017; He et al., 2018; Jian et al., 2018; Jolivet et al., 2001; Jolivet et al., 1999; Li et al., 2019; Lin et al., 2019; Liu et al., 2007a; Liu et al., 2005; Liu et al., 2007b; Mock et al., 1999; Pan et al., 2013; Qi et al., 2016; Rieser et al., 2006b; Rieser et al., 2009b; Sobel et al., 2001; Tian et al., 2020; Wang et al., 2016a; Wang et al., 2004; Wang et al., 2005; Wang et al., 2018; Wang et al., 2015; Wu et al., 2019c; Yuan et al., 2006; Zhang et al., 2017; Zhuang et al., 2018). This multi-pulse crustal deformation resulted in the exhumation and uplift of the mountain belts, forming pre-existing topographic reliefs in the northern Tibetan plateau. Provenance analyses on the Mesozoic sedimentary records in the Qaidam basin (Cheng et al., 2016a; Cheng et al., 2016b; Ritts and Biffi, 2000; Ritts and Biffi, 2001; Ritts et al., 1999; Robinson et al., 2003; Wu et al., 2011; Yu et al., 2017; Zhang et al., 2020; Zhao et al., 2020a; Zhao et al., 2020b), Hoh Xil basin (Staisch et al., 2020; Staisch et al., 2014; Wu et al., 2019b), Suganhu basin (Cheng et al., 2019d), Jiuquan basin (Chen et al., 2014; Cheng et al., 2019b), also demonstrated the existence of inherited relief in the northern Tibetan plateau. As shown by the detrital zircon geochronology, paleocurrent measurement, heavy mineral analysis, and petrology studies, pre-existing reliefs in the Eastern Kunlun Shan and the Qilian Shan shed materials into the southwestern and northeastern parts of the Qaidam basin during deposition of the Lulehe Fm. (Cheng et al., 2016a; Cheng et al., 2016b; Wang et al., 2020a; Wu et al., 2011; Yu et al., 2017; Zhao et al., 2020a). These pre-existing reliefs in the Eastern Kunlun Shan and the Qilian 
Shan were resulting in topographic load induced basement deflection of the Qaidam basin during the deposition of the Lulehe Fm. An early stage of exhumation of the Qilian Shan and the Altyn Tagh Shan is also supported by the growth strata shown on the seismic profile in the northwestern and northeastern edges of the basin (Cheng et al., 2019a; Cheng et al., 2019c; Cheng et al., 2019d; Yin et al., 2008a; Yin et al., 2008b). As shown on the isopach map of the Lulehe Fm. strata (Figs. 7, 12, 17a), the major depocenter was adjacent to the Qilian Shan while a few secondary depocenters were located along the southern and western margins of the basin. Despite uncertainties, the synchronous deformation along the western edge of the Qaidam basin might be associated with the initial left-lateral strike-slip faulting along the Altyn Tagh Fault (Cheng et al., 2015a; Cheng et al., 2016b; Yin et al., 2002).

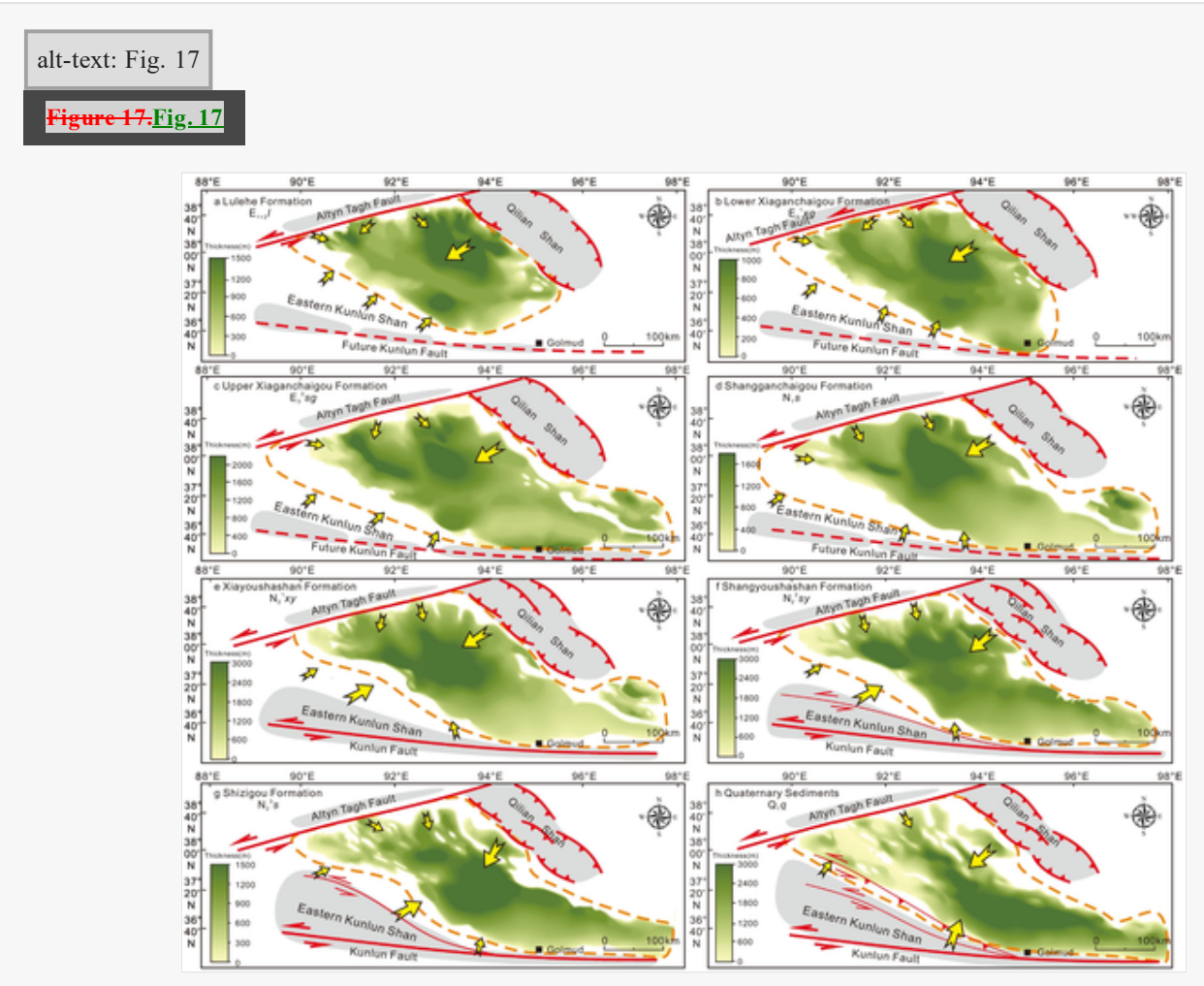

Sketched tectonic features in the Qaidam basin and surrounding orogenic belts on the isopach maps of the Cenozoic strata. The yellow arrows refer to the direction of the drainage system._(For interpretation of the references to colour in this figure legend, the reader is referred to the web version of this article.)

Integrated provenance analysis based on sedimentology evidence and detrital zircon geochronology show that the preCenozoic exhumed Eastern Kunlun Shan (including basement-exposed topographic highs) served as the dominant source of detrital materials for the Qaidam basin during the deposition of the Lulehe Fm. (Fig. 17a) and separated the Qaidam basin from the Hoh Xil basin to the south. Despite the existence of this relief, the Lulehe Fm. along the northern front of the Eastern Kunlun Shan is composed of distal fluvial to marginal lacustrine deposits and proximal fluvial deposits (Cheng et al., 2019a; Cheng et al., 2019c), indicating that the relief of the Eastern Kunlun Shan was limited and was likely located further south than its modern position. This inference of limited topography of the Eastern Kunlun Shan is consistent with flexural modeling results (Cheng et al., 2019a; Wang et al., 2021). Wang et al. (2021) applied flexural modeling to reconstructed the Paleogene isopach pattern obtained from seismic imaging of the Qaidam basin. Modeling result shows that the topographic load of the Eastern Kunlun Shan was much smaller than that of the Qilian Shan (Fig. 14a). Based on these lines of evidence, we proposed that the Qaidam basin should be considered as a flexural basin during the deposition of the Lulehe Fm.

\subsubsection{Basin-scale expansion of the Qaidam basin drainage system}

Based on the information derived from the isopach maps, seismic profiles, sedimentology, and detrital zircon geochronology, we propose a basin-scale expansion of the Qaidam basin from the deposition of the Lower Xiaganchaigou Fm. to that of the Shangganchaigou Fm. This expansion is characterized by the landward migration/retrogradation of the alluvial-fluvial facies deposits along the edges of the Qaidam basin (Fig. 15c-e)(Cheng et al., 2019c). Inside the basin, expansion of the drainage and deposition system translates into landward-onlapping reflectors shown on the seismic reflection profiles (Fig. 15g) (Cheng et al., 2016a; Cheng et al., 2019c), the outwards widening of the sediment deposition area as shown on the isopach maps (Figs. 5, 11, 17b-d), and the more diverse age distribution shown on detrital zircon age spectra (Fig. 16) (Cheng et al., 2016a; Cheng et al., 2019c).

Despite that left-lateral strike-slip faulting along the Altyn Tagh Fault might locally create extension along the fault zone, seismic profiles across the basin indicate a continuous contractional setting affecting the Qaidam basin, the Qilian Shan, and the Eastern Kunlun Shan throughout the Cenozoic (Cheng et al., 2016a; Cheng et al., 2019a; Cheng et al., 2019c; Cheng et al., 2016b; Cheng et al., 2017; Wei et al., 2016; Wu et al., 2014; Yin et al., 2008a; Yin et al., 2008b; 
Yin et al., 2007; Zhou et al., 2006). Continuous formation of growth strata can be observed in the Lower Xiaganchaigou, Upper Xiaganchaigou, and Shangganchaigou Fms. of the northern Qaidam basin (Fig. 9), indicating a contemporaneous uplift of the Qilian Shan seemingly incompatible with an overall widening of the basin (Cheng et al., 2019c). On the other hand, the depositional facies datasets provided by the Qinghai Oilfield, PetroChina, shows a distinct basin-ward shift of lithofacies associations, from proximal alluvial fan facies to distal lacustrine facies in plan view (Cheng et al., 2019c). Vertically, the coarse-grained alluvial fan and braided river deposits retrograded northward, from the deposition of the Lulehe Fm. to that of the Shangganchaigou Fm. In details, the alluvial fan facies of the Lulehe Fm. gradually evolved upward to braided river facies in the Lower Xiaganchaigou and Shangganchaigou Fms. As a consequence, in such a contractional setting, climate likely played a major role in reducing the formation of topographic relief, allowing for the expansion of drainage and deposition areas. A negative shift in $\delta^{18} \mathrm{O}$ values of marls/limestones from the Lower Xiaganchaigou Fm. to the Shangganchaigou Fm. (Cheng et al., 2019c; Li et al., 2016 ; Li et al., 2017; Mao et al., 2014b; Rieser et al., 2009a) and the discovery of the fishes living in warm freshwater environments (Yan et al., 2018; Yang et al., 2018), suggest that the regional climate was relatively wet climate with considerable precipitation at that time.

We thus propose that during the deposition of the Lower Xiaganchaigou Fm. to Shangganchaigou Fm., the regional climate changed toward wetter conditions triggering erosion in the uplifting ranges around the basin and allowing a landward expansion of the basin drainage area and deposition area. Although the southward basin expansion would lead to a potential connection between the Qaidam basin and the Hoh Xil basin to the south at that time (Cheng et al., 2016a; Cheng et al., 2019c; Mao et al., 2014a; McRivette et al., 2019; Yin et al., 2008b), the Eastern Kunlun Shan might still be partly uplifted. Except for a few minor depocenters in the western or eastern part of the basin, the major depocenter was consistently located near the geometric center of the basin. This continuous accumulation of materials derived from the surrounding mountain belts increased the sedimentation load, which further drove the subsidence, allowing for continuous sediment accommodation space (Fig. 17b-d) (Cheng et al., 2017; Métivier et al., 1998; Meyer et al., 1998).

\subsubsection{Isolation of the Qaidam basin}

From the deposition of the Xiayouoshashan Fm., the Qaidam basin has been gradually shrinking, as shown on the isopach maps by a reduction in sediment distribution area (Figs. 5, 17e-h). The most prominent change is that the southern edge of the basin migrated northwards compared to the previous period. This motion is reflecting the rapid uplift of the Eastern Kunlun Shan during deposition of the Xiayooushashan Fm. This is further supported by growth strata forming during the same period in the southern Qaidam basin (Cheng et al., 2016a; Cheng et al., 2018; Cheng et al., 2019a; Cheng et al., 2014; Cheng et al., 2017; Cheng et al., 2015c; Huang et al., 2020; Mao et al., 2014a; Wang et al., 2010b; Wu et al., 2014) and the increase in cooling rates evidenced by low-temperature thermochronology data in the Eastern Kunlun Shan (Dai et al., 2013; Duvall et al., 2013; Jolivet et al., 2001; Jolivet et al., 2003; Mao et al., 2014a; McRivette et al., 2019; Staisch et al., 2020; Wu et al., 2019a). Northwest and northeast of the basin, the tectonic uplift of the Altyn Tagh Shan and Qilian Shan, evidenced by low-temperature thermochronology data (Chen et al., 2009; Cheng et al., 2016c; Jolivet et al., 1999; Li et al., 2015b; Lin et al., 2015; Liu et al., 2007a; Pang et al., 2019a; Pang et al., 2019b; Wang et al., 2006; Wang et al., 2020b; Yin et al., 2002; Yu et al., 2019a; Yu et al., 2019b) and the development of growth strata along the margins of the Qaidam basin (Figs. 6a and 7d), forced the depocenter of the basin to gradually migrate eastward during the deposition of the Xiayoushashan, Shangyoushashan, Shzigou, and Qigequan Fms. (Cheng et al., 2015a; Cheng et al., 2015b; Cheng et al., 2016b; Cheng et al., 2019d; Meng and Fang, 2008; Wang et al., 2010b; Wang et al., 2010c; Wu et al., 2019d)(Fig. 2c). The deposition of the Shangyoushashan Fm., marks the onset of noticeable internal deformation in the Qaidam basin that will lead to partitioning during the Neogene (uplifted zone during the Neogene are represented by non-deposition areas on the isopach maps) (Fig. 17f-g). Seismic profiles show that these structures formed during the period extending from the deposition of the Xiayoushashan Fm. to that of the Qigequan Fm. (Figs. 6, 9-11). This internal deformation, added to the topographic growth of the surrounding ranges, further increased the shrinking of the Qaidam basin. However, during the same period, the regional climate became more arid (Heermance et al., 2013; Li et al., 2016; Miao et al., 2019; Zhuang et al., 2011a), and we might not rule out the possibility that the decrease in rainfall, by reducing the erosion rates, limited the sediment discharge in the basin, favoring its reduction in size. The Late Cenozoic evolution of the Qaidam basin was thus controlled by a complex combination of tectonic crustal thickening and relief building associated to a climate-driven reduction in erosion rates.

Overall, the Qaidam basin should be considered a superimposed basin, controlled during the Cenozoic by the major fault systems in the Altyn Tagh Shan, Qilian Shan, and Eastern Kunlun Shan. It cannot be simply summarized as a foreland basin, strike-slip full-part basin, or any other type of sedimentary basin. Given the multiple pulses of contractional deformation in the surrounding regions, the Qaidam basin might have experienced at least three stages of evolution during the Cenozoic, from a flexural basin during the deposition of the Lulehe Fm., to an expanding "cratonic basin" during the deposition of the Lower Xiaganchaigou, Upper Xiaganchaigou, and Shangganchaigou Fms., and finally to a completely isolated and partitioned endoreic basin from the deposition of the Xiayoushashan Fm. to the present. Besides the tectonics, climate change toward a wetter climate condition during the Paleogene contributed 
to the expansion of the basin, a trend that was inverted during the Neogene due to the superimposed effects of increased crustal shortening and aridity-driven decrease in erosion rates.

\subsection{Conclusion}

The compilation of the available sedimentology, tectonics, thermochronology, geochronology, and geophysical data in the Qaidam basin highlights the following points:

(1) Although the most recent "young ages" model for the Cenozoic strata in the Qaidam basin might work for the northeastern part of the basin, the traditional "old ages" model seems to fit reasonably well the deformation history obtained from combining growth-strata observations and thermochronology data in the northern and southern Qaidam basin. The Cenozoic lithostratigraphic units within the basin might be probably time-transgressive, but further investigation is urgently needed.

(2) The Neogene initiation of strike-slip faulting along the south-dipping faults that roots into the Eastern Kunlun Shan played an important role in the evolution of the southern Qaidam basin. The Eastern Kunlun Shan has been exhumed since the deposition of the Lulehe Fm., serving as a significant source to the sediments deposited in the Qaidam basin. The topographic relief in the Eastern Kunlun Shan seperated the Qaidam basin from the Hoh Xil basin to the south.

(3) The Qaidam basin is a superimposed sedimentary basin, which experienced three stages of evolution during the Cenozoic, from a flexural basin setting during the deposition of Lulehe Fm. Then the Qaidam basin became an outward expanding "cratonic basin" during the deposition of Lower Xiaganchaigou, Upper Xiaganchaigou, and Shangganchaigou formations, and finally became an isolated, partitioned, and closed basin from the deposition of the Xiayoushashan Fm. to the present. Both tectonics and climate play an important role in the evolution of the basin during the Cenozoic.

\section{Declaration of Competing Interest}

The authors declare that they have no known competing financial interests or personal relationships that could have appeared to influence the work reported in this paper.

\section{Acknowledgement}

We thank guidance from Carmala Garzione, Mark Allen, Gautam Mitra. This research was funded by grants from Open grant from the Lhasa National Geophysical Observation and Research Station[Instruction:

Change "Lhasa National Geophysical Observation and Research Station" to "Lhasa National Geophysical Observation and Research Station, Institute of Geology, China Earthquake Administration, Lhasa 850004, China"] (NORSLS2001), Open grant from Key Laboratory of Deep-Earth Dynamics of Ministry of Natural Resource, Institute of Geology, Chinese Academy of Geological Sciences, Beijing 100037, China (J1901), and Open project fund from the State Key Laboratory of Loess and Quaternary Geology, Institute of Earth Environment, CAS (No. SKLLQG1701 and No. SKLLQG1903), to F. Cheng, the Key Program of the National Natural Science Foundation of China (Grant No. 41930213 ) to Z. Guo, Youth Innovation Promotion Association CAS (Y201759) to X. Li. We are grateful to Editors

Q10 Prof. Carlo Doglioni and Prof. Andrea Zanchi and three anonymous referees for providing insightful comments.

\section{Appendix A.Appendix A Supplementary data}

Supplementary data to this article can be found online at https://doi.org/10.1016/j.earscirev.2021.103730.

\section{References}

(i) The corrections made in this section will be reviewed and approved by a journal production editor. The newly added/removed references and its citations will be reordered and rearranged by the production team.

Arnaud, N., Tapponnier, P., Roger, F., Brunel, M., Scharer, U., Chen, W., Xu, Z., 2003. Evidence for Mesozoic shear along the western Kunlun and Altyn-Tagh fault, northern Tibet (China). Journal of Geophysieal Researeh: Solid EarthJ. Geophys. Res. Solid Earth 108 (B1).

Q13 Baotian, P., Qingyang, L., Xiaofei, H., Haopeng, G., Zibian, L., Shaofei, J., Wanming, Y., 2013. Cretaceous and Cenozoic cooling history of the eastern Qilian Shan, north-eastern margin of the Tibetan Plateau: evidence from apatite fission-track analysis. Terra Nova 25 (6), 431-438.

Bosboom, R., Dupont-Nivet, G., Grothe, A., Brinkhuis, H., Villa, G., Mandic, O., Stoica, M., Huang, W., Yang, W., Guo, Z., Krijgsman, W., 2014. Linking Tarim Basin sea retreat (west China) and Asian aridification 
Burchfiel, B.C., Quidong, D., Molnar, P., Royden, L., Yipeng, W., Peizhen, Z., Weiqi, Z., 1989. Intracrustal detachment within zones of continental deformation. Geology 17 (8), 748-752.

Bush, M.A., Saylor, J.E., Horton, B.K., Nie, J., 2016. Growth of the Qaidam Basin during Cenozoic exhumation in the northern Tibetan Plateau: inferences from depositional patterns and multiproxy detrital provenance signatures. Lithosphere 8 (1), 58-82.

Chang, H., Ao, H., An, Z., Fang, X., Song, Y., Qiang, X., 2012. Magnetostratigraphy of the Suerkuli Basin indicates Pliocene (3.2 Ma) activity of the middle Altyn Tagh fault, northern Tibetan Plateau. Fournal of Asian Earth SeiencesJ. Asian Earth Sci. 44, 169-175.

Chang, H., Li, L., Qiang, X., Garzione, C.N., Pullen, A., An, Z., 2015. Magnetostratigraphy of Cenozoic deposits in the western Qaidam Basin and its implication for the surface uplift of the northeastern margin of the Tibetan Plateau. Earth and Planetary Seienee LettersEarth Planet. Sci. Lett. 430, 271-283.

Charreau, J., Chen, Y., Gilder, S., Dominguez, S., Avouac, J.-P., Sen, S., Sun, D., Li, Y., Wang, W.-M., 2005. Magnetostratigraphy and rock magnetism of the Neogene Kuitun He section (northwest China): implications for Late Cenozoic uplift of the Tianshan mountains. Earth and Planetary Seienee LettersEarth Planet. Sci. Lett. 230 (1), 177-192.

Charreau, J., Chen, Y., Gilder, S., Barrier, L., Dominguez, S., Augier, R., Sen, S., Avouac, J.P., Gallaud, A., Graveleau, F., 2009a. Neogene uplift of the Tian Shan Mountains observed in the magnetic record of the Jingou River section (northwest China). Tectonics 28 (2).

Charreau, J., Gumiaux, C., Avouac, J.-P., Augier, R., Chen, Y., Barrier, L., Gilder, S., Dominguez, S., Charles, N., Wang, Q., 2009b. The Neogene Xiyu Formation, a diachronous prograding gravel wedge at front of the Tianshan: climatic and tectonic implications. Earth and Planetary Seienee LettersEarth Planet. Sci. Lett. 287 (34), 298-310.

Chen, H., Lin, X., Guan, K., Xu, J., 1994. Early Pleistocene deposits and its lower boundary (Q/N) in Tianshan Mt., Xinjiang Region. Quaternary Seienees_Quaternary_Sci. 1, 38-47.

Chen, W.P., Chen, C.Y., Nábelek, ŁL., J., 1999. Present-day deformation of the Qaidam basin with implications for intra-continental tectonics. Tectonophysics 305 (1-31-3), 165-181.

Chen, X., Yin, A., Gehrels, G.E., Cowgill, E.S., Grove, M., Harrison, T.M., Wang, X.-F., 2003. Two phases of Mesozoic north-south extension in the eastern Altyn Tagh range, northern Tibetan Plateau. Tectonics 22 (5).

Chen, X., Yin, A., George, E.G., Jiang, R., Chen, Z., Bai, Y., 2009. Geothermochronology and textonic evolution of Eastern Altyn Tagh Mountains, Northwestern China. Earth Seienee FrontiersEarth Sci. Front. 16 (3), 207-219.

Chen, X., Mcrivette, M., Li, L., Yin, A., Jiang, R., Wan, J., Li, H., 2011. Thermochronologyical evidence for multi-phase uplifting of the East Kunlun Mountains, northern Tibetan Plateau. Geologieal Bulletin of ChinaGeol. Bull. China 30 (11), 1647-1660.

Chen, S., Wang, H., Wei, J., Lv, Z., Gan, H., Jin, S., 2014. Sedimentation of the Lower Cretaceous Xiagou Formation and its response to regional tectonics in the Qingxi Sag, Jiuquan Basin, NW China. Eretaeeous ResearehCretac. Res. 47, 72-86.

Cheng, F., Jolivet, M., Fu, S., Zhang, Q., Guan, S., Yu, X., Guo, Z., 2014. Northard gromen Fagh Range: $A$ new model aceounting for the Late Neogene strike-slip deformation of the SW Qaidam BasinNorthward growth of the Qimen Tagh Range: a new model accounting for the Late Neogene strike-slip deformation of the SW Q Qaidam Basin. Tectonophysics 632 (0), 32-47.

Cheng, F., Guo, Z., Jenkins, H.S., Fu, S., Cheng, X., 2015a. Initial rupture and displacement on the Altyn Tagh fault, northern Tibetan Plateau: constraints based on residual Mesozoic to Cenozoic strata in the western Qaidam Basin. Geosphere 11 (3), 921-942.

Cheng, F., Jolivet, M., Dupont-Nivet, G., Wang, L., Yu, X., Guo, Z., 2015b. Lateral extrusion along the Altyn Tagh Fault, Qilian Shan (NE Tibet): insight from a 3D crustal budget. Terra Nova 27 (6), 416-425.

Cheng, X., Fu, S., Wang, H., Yu, X., Cheng, F., Liu, R., Du, W., Guo, Z., 2015c. Geometry and kinematics of the Arlar strike-slip fault, SW Qaidam basin, China: new insights from 3-D seismic data. Journal of Asian Earth SeieneesJ. Asian Earth Sci. 98 (0), 198-208. 
Cheng, F., Fu, S., Jolivet, M., Zhang, C., Guo, Z., 2016a. Source to sink relation between the Eastern Kunlun

Range and the Qaidam Basin, northern Tibetan Plateau, during the Cenozoic. Geologieal Soeiety of Ameriea BulletinGeol. Soc. Am. Bull. 128 (1-z 1-2 ), 258-283.

Cheng, F., Jolivet, M., Fu, S., Zhang, C., Zhang, Q., Guo, Z., 2016b. Large-scale displacement along the Altyn Tagh Fault (North Tibet) since its Eocene initiation: insight from detrital zircon U-Pb geochronology and subsurface data. Tectonophysics 677-678, 261-279.

Cheng, X., Lin, X., Wu, L., Chen, H., Xiao, A., Gong, J., Zhang, F., Yang, S., 2016c. The exhumation history of north Qaidam thrust belt constrained by apatite fission track thermochronology: implication for the evolution of the Tibetan Plateau. Acta Geologiea Siniea (English Edition)Acta Geol. Sin. 90 (3), 870-883.

Cheng, F., Jolivet, M., Hallot, E., Zhang, D., Zhang, C., Guo, Z., 2017. Tectono-magmatic rejuvenation of the Qaidam craton, northern Tibet. Gondwana ResearehGondwana Res. 49, 248-263.

Cheng, F., Garzione, C., Jolivet, M., Guo, Z., Zhang, D., Zhang, C., 2018. A new sediment aecumulation model of cenozoie depositional ages From the Qaidam basin, Tibetan Plateat A new sediment accumulation model of cenozoic depositional ages from the Qaidam basin, Tibetan Plateau. Journal of Geophysieal Researeh: Earth SurfaceJ. Geophys. Res. Earth Surf. 123 (11), 3101-3121.

Cheng, F., Garzione, C., Jolivet, M., Guo, Z., Zhang, D., Zhang, C., Zhang, Q., 2019a. Initial deformation of the northern Tibetan Plateat: insights From deposition of the Lulehe formation in the Qaidam basinInitial deformation of the northern Tibetan Plateau: insights from deposition of the Lulehe formation in the Qaidam basin. Tectonics 38, 741-766.

Cheng, F., Garzione, C., Jolivet, M., Wang, W., Dong, J., Richter, F., Guo, Z., 2019b. Provenance analysis of the Yumen Basin and northern Qilian Shan: implications for the pre-collisional paleogeography in the NE Tibetan plateau and eastern termination of Altyn Tagh fault. Gondwana ResearehGondwana Res. 65, 156-171.

Cheng, F., Garzione, C.N., Mitra, G., Jolivet, M., Guo, Z., Lu, H., Li, X., Zhang, B., Zhang, C., Zhang, H., Wang, L., 2019c. The interplay between climate and tectonics during the upward and outward growth of the Qilian Shan orogenic wedge, northern Tibetan Plateau. Earth-Seience ReviewsEarth Sci. Rev. 198, 102945.

Cheng, F., Jolivet, M., Guo, Z., Lu, H., Zhang, B., Li, X., Zhang, D., Zhang, C., Zhang, H., Wang, L., Wang, Z., Zhang, Q., 2019d. Jurassie Early Cenozoie Teetonie inversion in the Qilian Shan and Qaidam basin, North Tibet: new insight From seismie refleetion, isopach mapping, and drill core data Jurassic-Early Cenozoic Tectonic inversion in the Qilian Shan and Qaidam basin, North Tibet: new insight from seismic reflection, isopach mapping, and drill core data. Journal of Geophysieal Research: Solid EarthJ. Geophys. Res. Solid Earth 124 (11), 12077-12098.

Clark, M., Farley, K., Zheng, D., Wang, Z., Duvall, A., 2010. Early Cenozoic faulting of the northern Tibetan Plateau margin from apatite (U-Th)/He ages. Earth and Planetary Seienee LettersEarth Planet. Sci. Lett. 296 (1), $78-88$.

Cumming, V.M., Selby, D., Lillis, P.G., 2012. Re-Os geochronology of the lacustrine Green River Formation: insights into direct depositional dating of lacustrine successions, Re-Os systematics and paleocontinental weathering. Earth and Planetary Seienee LettersEarth Planet. Sci. Lett. 359-360, 194-205.

Cumming, V.M., Selby, D., Lillis, P.G., Lewan, M.D., 2014. Re-Os geochronology and Os isotope fingerprinting of petroleum sourced from a Type I lacustrine kerogen: insights from the natural Green River petroleum system in the Uinta Basin and hydrous pyrolysis experiments. Geochimiea et Cosmochimica ActaGeochim. Cosmochim. Acta 138, 32-56.

Dai, S., Fang, X., Song, C., Gao, J., Gao, D., Li, J., 2005. Early tectonic uplift of the northern Tibetan Plateau. Ehinese Seienee BulletinChin. Sci. Bull. 50 (15), 1642.

Dai, J.G., Zhao, X.X., Wang, C.S., Zhu, L.D., Li, Y.L., Finn, D., 2012. The vast proto-Tibetan Plateau: new constraints from Paleogene Hoh Xil Basin. Gondwana ResearehGondwana Res. 22 (2), 434-446.

Dai, J., Wang, C., Hourigan, J., Santosh, M., 2013. Multi-stage tectono-magmatic events of the Eastern Kunlun Range, northern Tibet: insights from U-Pb geochronology and (U-Th)/He thermochronology. Tectonophysics 599, 97-106.

Dewey, J.F., Bird, J.M., 1970. Mountain belts and the new global tectonics. Journal of Geophysieal Researeh $\underline{\text { J. }}$ Geophys. Res. 75 (14), 2625-2647.

Dewey, J.F., Shackleton, R.M., Chengfa, C., Yiyin, S., 1988. The tectonic evolution of the Tibetan Plateau. Philosophieal Transactions of the Royal Society of London. Series $\Lambda$, Mathematieal and Physieal 
Ding, L., Xu, Q., Yue, Y., Wang, H., Cai, F., Li, S., 2014. The Andean-type Gangdese Mountains: paleoelevation record from the Paleocene-Eocene Linzhou Basin. Earth and Planetary Seience LettersEarth Planet. Sci. Lett. 392, 250-264.

Drost, K., Chew, D., Petrus, J.A., Scholze, F., Woodhead, J.D., Schneider, J.W., Harper, D.A.T., 2018. An Image mapping approach to $\mathrm{U}-\mathrm{Pb} \mathrm{LA}-\mathrm{ICP}-\mathrm{MS}$ earbonate dating and Applieations to direet dating of earbonate sedimentation $\underline{A n}$ image mapping_approach to U-Pb LA-ICP-MS carbonate dating and applications to direct dating of carbonate sedimentation. Geochemistry, Geophysies, GeosystemsGeochem. Geophys. Geosyst. 19 (12), 4631-4648.

Du, D.-D., Zhang, C.-J., Mughal, M.S., Wang, X.-Y., Blaise, D., Gao, J.-P., Ma, Y., Luo, X.-R., 2018. Đetrital apatite fission traek eonstraints on Cenozoie teetonic evolution of the northeastern Qinghai-Tibet Plateat, China: Evidenee from Cenozoie strata in Lulehe seetion, Northern Qaidam BasinDetrital apatite fission track constraints on Cenozoic tectonic evolution of the northeastern Qinghai-Tibet Plateau, China: evidence from Cenozoic strata

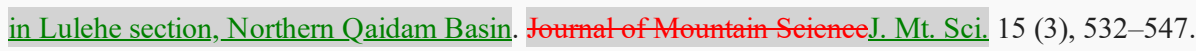

Dupont-Nivet, G., Horton, B., Butler, R., Wang, J., Zhou, J., Waanders, G., 2004. Paleogene clockwise tectonic rotation of the Xining-Lanzhou region, northeastern Tibetan Plateau. J. Geophys. Res. Geophys. Res. 109, B04401.

Dupont-Nivet, G., Krijgsman, W., Langereis, C.G., Abels, H.A., Dai, S., Fang, X., 2007. Tibetan plateau aridification linked to global cooling at the Eocene-Oligocene transition. Nature 445 (7128), 635-638.

Dupont-Nivet, G., Hoorn, C., Konert, M., 2008. Fibetan uplift prior to the Eocene-Oligocene climate transition: Evidenee from pollen analysis of the Xining BasinTibetan uplift prior to the Eocene-Oligocene climate transition: evidence from pollen analysis of the Xining Basin. Geology 36 (12), 987-990.

Dupont-Nivet, G., Lippert, P.C., Van Hinsbergen, D.J.J., Meijers, M.J.M., Kapp, P., 2010. Palaeolatitude and age of the Indo-Asia collision: palaeomagnetic constraints. Geophysieal Journal InternationalGeophys. J. Int. 182 (3), 1189-1198.

Duvall, A.R., Clark, M.K., van der Pluijm, B.A., Li, C., 2011. Direct dating of Eocene reverse faulting in northeastern Tibet using Ar-dating of fault clays and low-temperature thermochronometry. Earth and Planetary Seience LettersEarth Planet. Sci. Lett. 304 (3-4), 520-526.

Duvall, A.R., Clark, M.K., Kirby, E., Farley, K.A., Craddock, W.H., Li, C., Yuan, D.-Y., 2013. Lowtemperature thermochronemetry along the Kunlun and Haiyuan Faults, NE Tibetan Plateau: Evidenee for kinematic change during late-stage orogenesisLow-temperature thermochronometry along the Kunlun and Haiyuan Faults, NE Tibetan Plateau: evidence for kinematic change during late-stage orogenesis. Tectonics 32 (5), 1190-1211.

England, P., Searle, M., 1986. The Cretaceous-Tertiary deformation of the Lhasa block and its implications for crustal thickening in Tibet. Tectonics 5 (1), 1-14.

Fang, X., Gao, J., Zhang, W., Wang, Y., Liu, D., 2006. The Qigequan Yueyashan struetures in the western Qaidam Basin in front of the Altyn Mountain: detailed evolution and selection of prospective targets The Qigequan-Yueyashan Structures in the Western Qaidam Basin in Front of the Altyn Mountain: Detailed Evolution and Selection of Prospective Targets. Qinghai Oilfiled Company, PetroChina.

Fang, X., Zhang, W., Meng, Q., Gao, J., Wang, X., King, J., Song, C., Dai, S., Miao, Y., 2007. High-resolution magnetostratigraphy of the Neogene Huaitoutala section in the eastern Qaidam Basin on the NE Tibetan Plateau, Qinghai Province, China and its implication on tectonic uplift of the NE Tibetan Plateau. Earth and Planetary Seienee LettersEarth Planet. Sci. Lett. 258 (1-2 $\underline{1-2})$, 293-306.

Fang, X., Galy, A., Yang, Y., Zhang, W., Ye, C., Song, C., 2019. Paleogene global cooling-induced temperature feedback on chemical weathering, as recorded in the northern Tibetan Plateau. Geology 47 (10), 992-996.

Feng, X., Dai, W., 2004. Lateral migration of fault activity in Weihe basin. Acta Seismolegiea SinieaActa Seismol. Sin. 17 (2), 190-199.

Q14 Finzel, E.S., Rosenblume, J.A., 2020. Dating lacustrine carbonate strata with detrital zircon U-Pb geochronology. Geology..

Fu, L., GUan, P., Jian, X., Ruijuan, L., Feng, F., An, Q., Fan, C., 2012. Sedimentary genetic types of coarse fragment of Paleogene Lulehe Formation in Qaidam bain and time limit of the Tibetan Plateau Uplift. Nattral 
Fu, L., Guan, P., Zhao, W., Wang, M., Zhang, Y., Lu, J., 2013. Heavy mineral feature and provenance analysis of Paleogene Lulehe Formation in Qaidam Basin. Aeta Petrologiea SinieaActa Petrol. Sin. 29 (8), 2867-2875.

Fu, S., Ma, D., Guo, Z., Cheng, F., 2015. Strike-slip superimposed Qaidam Basin and its control on oil and gas accumulation, NW China. Petroleum Exploration and DevelopmentPet. Explor. Dev. 42 (6), 778-789.

Gaboardi, M., Deng, T., Wang, Y., 2005. Middle Pleistocene climate and habitat change at Zhoukoudian, China, from the carbon and oxygen isotopic record from herbivore tooth enamel. Quaternary ResearehQuat. Res. 63 (3), 329-338.

Gong, Q.S., Shou, J.F., Huang, G.P., Li, S.M., Wang, Y.Q., 2012. Sedimentary characteristic of braided delta in Lulehe Formation of Kunbei oilfield in Qaidam Basin. Ehinese Journal of GeologyChin. J. Geol. 47 (1), 116128.

He, P., Song, C., Wang, Y., Chen, L., Chang, P., Wang, Q., Ren, B., 2017. Cenozoic exhumation in the Qilian Shan, northeastern Tibetan Plateat: Evidence from detrital fission track thermochronology in the Jituquan BasinCenozoic exhumation in the Qilian Shan, northeastern Tibetan Plateau: evidence from detrital fission track thermochronology in the Jiuquan Basin. Journal of Geophysieal Researeh: Solid Earth. Geophys. Res. Solid Earth 122 (8), 6910-6927.

He, P., Song, C., Wang, Y., Meng, Q., Chen, L., Yao, L., Huang, R., Feng, W., Chen, S., 2018. Cenozoic deformation history of the Qilian Shan (northeastern Tibetan Plateau) constrained by detrital apatite fission-track thermochronology in the northeastern Qaidam Basin. Tectonophysics 749, 1-11.

Heermance, R., Chen, J., Burbank, D.W., Wang, C., 2007. Chronology and tectonic controls of Late Tertiary deposition in the southwestern Tian Shan foreland, NW China. Basin ResearehBasin Res. 19 (4), 599-632.

Heermance, R., Pullen, A., Kapp, P., Garzione, C., Bogue, S., Ding, L., Song, P., 2013. Climatic and tectonic controls on sedimentation and erosion during the Pliocene-Quaternary in the Qaidam Basin (China). Geologieal Soeiety of Ameriea BulletinGeol. Soc. Am. Bull. 125 (5-6 $\underline{5-6}), 833-856$.

Heilbronn, G., Boulvais, P., Marchand, E., Robin, C., Bourquin, S., Barrier, L., Jia, Y., Fu, B., Jolivet, M., 2015. Stable isotope characterization of pedogenic and lacustrine carbonates from the Chinese Tian Shan: constraints on the Mesozoic-Lower Cenozoic palaeoenvironmental evolution. Chemie der ErdeGeochemistry Chemie der Erde Geochem. 75 (1), 133-141.

Horton, B., Dupont-Nivet, G., Zhou, J., Waanders, G., Butler, R., Wang, J., 2004. Mesozoic-Cenozoic evolution of the Xining-Minhe and Dangchang basins, northeastern Tibetan Plateau: magnetostratigraphic and biostratigraphic results. Journal of Geophysieal Researeh: Solid EarthJ. Geophys. Res. Solid Earth 109 (B4).

Hu, X., Garzanti, E., Moore, T., Raffi, I., 2015. Direct stratigraphic dating of India-Asia collision onset at the Selandian (middle Paleocene, 59 \pm 1 Ma). Geology 43 (10), 859-862.

Huang, B., Piper, J.D., Qiao, Q., Wang, H., Zhang, C., 2010. Magnetostratigraphic and rock magnetic study of the Neogene upper Yaha section, Kuche Depression (Tarim Basin): implications to formation of the Xiyu conglomerate formation, NW China. Journal of Geophysieal Research: Solid EarthJ. Geophys. Res. Solid Earth 115 (B1).

Huang, K., Wu, L., Zhang, J., Zhang, Y., Xiao, A., Lin, X., Wang, L., Chen, H., 2020. Struettral coupling Between the Qiman Tagh and the Qaidam Basin, Northern Tibetan Plateatt: \ perspeetive From the Yingxiong range by integrating field mapping, seismic imaging, and analogue modelingStructural coupling between the Qiman Tagh and the Q $\underline{\text { aidam Basin, Northern Tibetan Plateau: a perspective from the Yingxiong range by }}$ integrating field mapping, seismic imaging, and analogue modeling. Tectonics 39 (12) e2020TC006287.

Hubbard, J., Shaw, J.H., 2009. Uplift of the Longmen Shan and Tibetan plateau, and the 2008 Wenchuan ( $\mathrm{M}=7.9$ ) earthquake. Nature 458 (7235), 194-197.

Huo, G.M., 1990. Petroleum geology of China: Oil fields in Qianghai and Xizang (in Chinese with English abstract)Petroleum Geology of China: Oil Fields in Qianghai and Xizang_(in Chinese with English Abstract). 14. Chinese Petroleum Industry Press 483 pp..

I.G.S.Q.P, 2004. The Report of Regional Geological Survey at Scale 1:250000, Institute of Geological Survey of Qinhai Province, Xining.

I.G.S.S.P, 2003. The Report of Regional Geological Survey at Scale 1:250000. Institute of Geological Survey of Shanxi Province, Xi'an. Xi'an. 
Ji, J., Zhang, K., Clift, P.D., Zhuang, G., Song, B., Ke, X., Xu, Y., 2017. High-resolution magnetostratigraphic study of the Paleogene-Neogene strata in the Northern Qaidam Basin: implications for the growth of the Northeastern Tibetan Plateau. Gondwana ResearehGondwana Res. 46, 141-155.

Jian, X., Guan, P., Zhang, W., Liang, H., Feng, F., Fu, L., 2018. Late Cretaceous to early Eocene deformation in the northern Tibetan Plateau: detrital apatite fission track evidence from northern Qaidam basin. Gondwana ResearehGondwana Res. 60, 94-104.

Jin, Q., Zha, M., Liu, Z., Gao, X.Z., Peng, D.H., Lin, L.M., 2002. Geology and Geochemistry of source rocks in the Qaidam Basin, NW CHina. Journal of Petroleum GeologyJ. Pet. Geol. 25 (2), 219-238.

Jolivet, M., Roger, F., Arnaud, N., Brunel, M., Tapponnier, P., Seward, D., 1999. Histoire de l'exhumation de l'Altun Shan: indications sur l'âge de la subduction du bloc du Tarim sous le système de l'Altyn Tagh (Nord Tibet). Comptes Rendus de l'Aeadémie des Seienees-Series IIA-Earth and Planetary SeieneeComptes Rendus Acad. Sci. 329 (10), 749-755.

Jolivet, M., Brunel, M., Seward, D., Xu, Z., Yang, J., Roger, F., Tapponnier, P., Malavieille, J., Arnaud, N., Wu, C., 2001. Mesozoic and Cenozoic tectonics of the northern edge of the Tibetan plateau: fission-track constraints. Tectonophysics 343 (1-z1-2), 111-134.

Jolivet, M., Dempster, T., Cox, R., 2003. Répartition de l'uranium et du thorium dans les apatites: implications pour la thermochronologie U Th/He. Comptes Rendus GeoseieneeCompt. Rendus Geosci. 335 (12), 899-906.

Jolivet, M., Barrier, L., Dauteuil, O., Laborde, A., Li, Q., Reichenbacher, B., Popescu, S.-M., Sha, J., Guo, Z., 2018. Late Cretaceous-Palaeogene topography of the Chinese Tian Shan: new insights from geomorphology and sedimentology. Earth and Planetary Seience LettersEarth Planet. Sci. Lett. 499, 95-106.

Jordan, T.E., 1981. Thrust loads and foreland basin evolution, Cretaceous, western United States. AAPG bulletinAAPG Bull. 65 (12), 2506-2520.

Ke, X., Ji, J., Zhang, K., Kou, X., Song, B., Wang, C., 2013. Magnetostratigraphy and anisotropy of Magnetie suseeptibility of the Lulehe formation in the Northeastern Qaidam basinMagnetostratigraphy and anisotropy of magnetic susceptibility of the Lulehe formation in the Northeastern Qaidam basin. Acta Geologiea SinieaEnglish EditionActa Geol. Sin. Eng. Ed. 87 (2), 576-587.

Kidd, W., Yusheng, P., Chengfa, C., Coward, M.P., Dewey, J.F., Gansser, A., Molnar, P., Shackleton, R.M., Yiyin, S., 1988. Geological mapping of the 1985 Chinese-British Tibetan (Xizang-Qinghai) Plateau Geotraverse route. Phil. Trans. R. Soc. Lond. A 327 (1594), 287-305.

Lease, R.O., 2014. Cenozoic mountain building on the northeastern Tibetan Plateau. Geologieal Society of America Special PapersGeol. Soc. Am. Spec. Pap. 507, 115-127.

Lease, R.O., Burbank, D.W., Hough, B., Wang, Z., Yuan, D., 2012. Pulsed Miocene range growth in northeastern Tibet: insights from Xunhua Basin magnetostratigraphy and provenance. Geologieal Soeiety of Ameriea BulletinGeol. Soc. Am. Bull. 124 (5-65-6), 657-677.

Li, L., Guo, Z., Guan, S., Zhou, S., Wang, M., Fang, Y., Zhang, C., 2015a. Heavy mineral assemblage characteristics and the Cenozoic paleogeographic evolution in southwestern Qaidam Basin. Seience China Earth SeieneesSci. China Earth Sci. 58 (6), 859-875.

Li, M., Tang, L., Yuan, W., 2015b. Middle Miocene-Pliocene activities of the North Altyn fault system: evidence from apatite fission track data. Arabian Journal of GeoseieneesArab. J. Geosci. 8 (11), 9043-9054.

Li, L., Garzione, C.N., Pullen, A., Chang, H., 2016. Early-middle Miocene topographic growth of the northern Tibetan Plateau: stable isotope and sedimentation evidence from the southwestern Qaidam basin. Palaeogeography, Palaeoclimatology, Palaeoeeology Palaeogeogr. Palaeoclimatol. Palaeoecol. 461, 201-213.

Li, L.-L., Wu, C.-D., Fan, C.-F., Li, J.-J., Zhang, C.-H., 2017. Carbon and oxygen isotopic constraints on paleoclimate and paleoelevation of the southwestern Qaidam basin, northern Tibetan Plateau. Geoseience FrontiersGeosci. Front. 8 (5), 1175-1186.

Li, J., Yue, L., Roberts, A., Hirt, A.M., Pan, F., Guo, L., Xu, Y., Xi, R., Guo, L., Qiang, X., 2018. Global cooling and enhanced Eocene Asian mid-latitude interior aridity. Nature communieations Nat. Commun. 9 (1), 3026 .

Li, B., Chen, X., Zuza, A.V., Hu, D., Ding, W., Huang, P., Xu, S., 2019. Cenozoic cooling history of the North Qilian Shan, northern Tibetan Plateau, and the initiation of the Haiyuan fault: Constraints from apatite-and zircon-fission track thermochronology. Tectonophysics 751, 109-124. 
Li, C., Zheng, D., Zhou, R., Yu, J., Wang, Y., Pang, J., Wang, Y., Hao, Y., Li, Y., 2020. Late Oligocene tectonic uplift of the East Kunlun Shan: expansion of the northeastern Tibetan Plateau. Geophysieal Researeh LettersGeophys. Res. Lett. n/a(n/a): e2020GL091281[Instruction: This reference should be deleted].

Li, C., Zheng, D., Zhou, R., Yu, J., Wang, Y., Pang, J., Wang, Y., Hao, Y., Li, Y., 2021. Late oligocene tectonic uplift of the East Kunlun Shan: expansion of the northeastern Tibetan plateau. Geophys. Res. Lett. 48 (3) e2020GL091281.

Lin, X., Zheng, D., Sun, J., Windley, B.F., Tian, Z., Gong, Z., Jia, Y., 2015. Detrital apatite fission track evidence for provenance change in the Subei Basin and implications for the tectonic uplift of the Danghe Nan Shan (NW China) since the mid-Miocene. Journal of Asian Earth Seienees. Asian Earth Sci. 111, 302-311.

Lin, X., Tian, Y., Donelick, R.A., Liu-Zeng, J., Cleber, S.J., Li, C.a., Wu, Q., Li, Z., 2019. Mesozoic and Eenozoie teetonies of the northeastern edge of the Tibetan plateat: Evidenee from modern river detrital apatite fission-track age constraintsMesozoic and Cenozoic tectonics of the northeastern edge of the Tibetan plateau: evidence from modern river detrital apatite fission-track age constraints. Journal of $A$ sian Earth Seienees $\underline{J}$. Asian Earth Sci. 170, 84-95.

Lin, J., Dai, J.-G., Zhuang, G., Jia, G., Zhang, L., Ning, Z., Li, Y., Wang, C., 2020. Late Eocene-Oligocene high relief Paleotopography in the North Central Tibetan Plateau: insights from detrital zircon U-Pb geochronology and leaf wax hydrogen isotope studies. Tectonics 39 (2) e2019TC005815.

Liu, Z.Q., 1988. In: C.I.o.G.a.M. Resources (Ed.), Geologic Map of the Qinghai-Xizhang Plateau and its Neighboring Regions. Geologic Publishing House, Beijing.

Liu, Y.J., Genser, J., Neubauer, F., Jin, W., Ge, X.H., Handler, R., Takasu, A., 2005. ${ }^{40} \mathrm{Ar} /{ }^{39} \mathrm{Ar}$ mineral ages from basement rocks in the Eastern Kunlun Mountains, NW China, and their tectonic implications. Tectonophysics 398 (3-4 $\underline{3-4}), 199-224$.

Liu, Y., Franz, N., Ge, X., Johann, G., Yuan, S., Li, W., Gong, Q., Chen, Y., 2007a. Geochronology of the Altun fault zone and rising of the Altun mountains. Chinese Journal of Geology Chin. J. Geol. 42 (1), 134-146.

Liu, Y.J., Neubauer, F., Genser, J., Ge, X.H., Takasu, A., Yuan, S.H., Chang, L.H., Li, W.M., $2007 b$. Geochronology of the initiation and displacement of the Altyn Strike-Slip Fault, western China. Journal of Asian Earth Seienees J. Asian Earth Sci. 29 (2), 243-252.

Liu, D., Li, H., Sun, Z., Pan, J., Wang, M., Wang, H., Marie, L., 2017. AFT dating constrains the Cenozoic uplift of the Qimen Tagh Mountains, Northeast Tibetan Plateau, comparison with LA-ICPMS Zircon U-Pb ages. Gondwana ResearehGondwana Res. 41, 438-450.

Liu, R., Chen, Y., Yu, X., Du, W., Cheng, X., Guo, Z., 2019. An analysis of Distributed strike-slip shear deformation of the Qaidam Basin, northern Tibetan PlateatAn analysis of distributed strike-slip shear deformation of the Qaidam Basin, northern Tibetan Plateau. Geophysieal Research LettersGeophys. Res. Lett. $46(8), 4202-4211$.

Lu, H., Xiong, S., 2009. Magnetostratigraphy of the Dahonggou section, northern Qaidam Basin and its bearing on Cenozoic tectonic evolution of the Qilian Shan and Altyn Tagh Fault. Earth and Planetary Seience LettersEarth Planet. Sci. Lett. 288 (3), 539-550.

Ma, D., Wang, Y., 2015. New understandings and exploration discovery of Paleogene reservoirs of Kunbei fault terrace belt, Qaidam Basin, NW China. Petroleum Exploration and DevelopmentPet. Explor. Dev. 42 (4), 580588.

Mack, G.H., Rasmussen, K.A., 1984. Alluvial-fan sedimentation of the Cutler Formation (PermoPennsylvanian) near Gateway, Colorado. Geologieal Seciety of Ameriea BulletinGeol. Soc. Am. Bull. 95 (1), $109-116$.

Mao, L., Xiao, A., Wu, L., Li, B., Wang, L., Lou, Q., Dong, Y., Qin, S., 2014a. Cenozoic tectonic and sedimentary evolution of southern Qaidam Basin, NE Tibetan Plateau and its implication for the rejuvenation of Eastern Kunlun Mountains. Seienee China Earth SeieneesSci. China Earth Sci. 57 (11), 2726-2739.

Mao, L., Yi, H., Ji, C., Xia, G., 2014b. Petrography and carbon-oxygen isotope characteristics of the cenozoic lacustrine carbonate rocks in Qaidam Basin. Geologieal Seienee and Teehnology InformationGeol. Sci. Technol. Inf. 33 (1), 41-48.

McRivette, M.W., Yin, A., Chen, X., Gehrels, G.E., 2019. Cenozoic basin evolution of the central Tibetan plateau as constrained by U-Pb detrital zircon geochronology, sandstone petrology, and fission-track thermochronology. Tectonophysics $751,150-179$. 
Meijer, N., Dupont-Nivet, G., Abels, H.A., Kaya, M.Y., Licht, A., Xiao, M., Zhang, Y., Roperch, P., Poujol,

M., Lai, Z., 2019. Central Asian moisture modulated by proto-Paratethys Sea incursions since the early Eocene. Earth Planetary Seienee LettersEarth Planet. Sci. Lett. 510, 73-84.

Meng, Q.R., Fang, X., 2008. Cenozoic tectonic development of the Qaidam Basin in the northeastern Tibetan Plateau. Geologieal Society of $A$ meriea Special PapersGeol. Soc. Am. Spec. Pap. 444, 1-24.

Meng, Q.R., Hu, J.M., Yang, F.Z., 2001. Timing and magnitude of displacement on the Altyn Tagh fault: constraints from stratigraphic correlation of adjoining Tarim and Qaidam basins, NW China. Terra Nova 13 (2), $86-91$.

Q16 Meng, Q.-A., Wang, X., Huo, Q.-L., Dong, Z.-L., Li, Z., Tessalina, S.G., Ware, B.D., McInnes, B.I.A., Wang, X.-L., Liu, T., Zhang, L., 2020. Rhenium-osmium (Re-Os) geochronology of crude oil from lacustrine source rocks of the Hailar Basin, NE China. Petroleum SeieneePet. Sci.

Métivier, F., Gaudemer, Y., Tapponnier, P., Meyer, B., 1998. Northeast of the Tibet plateat dedueed from balaneed reeonstrution of two depositional areas: The Qaidam and Hexi Corridor basins, China Northeastward growth of the Tibet plateau deduced from balanced reconstruction of two depositional areas: the Q Q aidam and Hexi Corridor basins, China. Tectonics 17 (6), 823-842.

Meyer, B., Tapponnier, P., Bourjot, L., Metivier, F., Gaudemer, Y., Peltzer, G., Shunmin, G., Zhitai, C., 1998. Crustal thickening in Gansu-Qinghai, lithospheric mantle subduction, and oblique, strike-slip controlled growth of the Tibet plateau. Geophysieal Journal InternationalGeophys. J. Int. 135 (1), 1-47.

Miao, Y., Fang, X., Herrmann, M., Wu, F., Zhang, Y., Liu, D., 2011. Miocene pollen record of KC-1 core in the Qaidam Basin, NE Tibetan Plateau and implications for evolution of the East Asian monsoon. Palaeogeography, Palaeelimatology, Palae eology Palaeogeogr. Palaeoclimatol. Palaeoecol. 299 (1), 30-38.

Miao, Y., Wu, F., Chang, H., Fang, X., Deng, T., Sun, J., Jin, C., 2016. A Late-Eocene palynological record from the Hoh Xil Basin, northern Tibetan Plateau, and its implications for stratigraphic age, paleoclimate and paleoelevation. Gendwana ResearehGondwana Res. 31, 241-252.

Miao, Y., Wu, F., Warny, S., Fang, X., Lu, H., Fu, B., Song, C., Yan, X., Escarguel, G., Yang, Y., Meng, Q., Shi, P., 2019. Miocene fire intensification linked to continuous aridification on the Tibetan Plateau. Geology 47 (4), 303-307.

Mock, C., Arnaud, N.O., Cantagrel, J.M., 1999. An early unroofing in northeastern Tibet? Constraints from ${ }^{40}$ $\mathrm{Ar} /{ }^{39} \mathrm{Ar}$ thermochronology on granitoids from the eastern Kunlun range (Qianghai, NW China). Earth and Planetary Seienee LettersEarth Planet. Sci. Lett. 171 (1), 107-122.

Mu, J., 2002. The features of tertiary sequence stratigraphy and their controlling faetors in the Hong-Shi area of Qaidam basinThe Features of Tertiary Sequence Stratigraphy and their Controlling Factors in the Hong-Shi Area of Qaidam Basin. China University of Geosciences, Beijing 163 pp..

Nie, J., Garzione, C., Su, Q., Liu, Q., Zhang, R., Heslop, D., Necula, C., Zhang, S., Song, Y., Luo, Z., 2017. Dominant 100,000-year precipitation cyclicity in a late Miocene lake from northeast Tibet. Seienee AdvaneesSci. Adv. 3 (3).

Nie, J., Ren, X., Saylor, J.E., Su, Q., Horton, B.K., Bush, M.A., Chen, W., Pfaff, K., 2019. Magnetic polarity stratigraphy, provenance, and paleoclimate analysis of Cenozoic strata in the Qaidam Basin, NE Tibetan Plateau. GSA BulletinGSA Bull. 132 (1-2 $\underline{1-2}), 310-320$.

Pang, X.Q., Li, Y.X., Jiang, Z.X., 2004. Key geological controls on migration and accumulation for hydrocarbons derived from mature source rocks in Qaidam Basin. Journal of Petroleum Seienee and EngineeringJ. Pet. Sci. Eng: 41 (1-3), 79-95.

Pang, J., Yu, J., Zheng, D., Wang, W., Ma, Y., Wang, Y., Li, C., Li, Y., Wang, Y., 2019a. Neogene expansion of the Qilian Shan, north Tibet: implications for the dynamic evolution of the Tibetan Plateau. Tectonics 38 (3), $1018-1032$.

Pang, J., Yu, J., Zheng, D., Wang, Y., Zhang, H., Li, C., Wang, W., Hao, Y., 2019b. Constraints of new apatite fission-track ages on the tectonic pattern and geomorphic development of the northern margin of the Tibetan Plateau. Journal of Asian Earth SeieneesJ. Asian Earth Sci. 181, 103909.

QBGMR, 1991. Regional Geology of Qinghai Province. Geological Publishing House, Beijing 662 pp..

Qi, B., Hu, D., Yang, X., Zhang, Y., Tan, C., Zhang, P., Feng, C., 2016. Apatite fission track evidence for the Cretaceous-Cenozoic cooling history of the Qilian Shan (NW China) and for stepwise northeastward growth of 
Rasbury, E.T., Cole, J.M., 2009. Directly dating geologic events: U-Pb dating of carbonates. Reviews of GeophysiesRev. Geophys. 47 (3).

Rieser, A.B., Liu, Y., Genser, J., Neubauer, F., Handler, R., Friedl, G., Ge, X.H., 2006a. ${ }^{40} \mathrm{Ar} /{ }^{39} \mathrm{Ar}$ ages of detrital white mica constrain the Cenozoic development of the intracontinental Qaidam Basin, China. GSA BulletinGSA Bull. 118 (11/12), 1522-1534.

Rieser, A.B., Liu, Y., Genser, J., Neubauer, F., Handler, R., Ge, X.-H., 2006b. Uniform Permian 40Ar/39Ar detrital mica ages in the eastern Qaidam Basin (NW China): where is the source? Terra Nova 18 (1), 79-87.

Rieser, A.B., Bojar, A.-V., Neubauer, F., Genser, J., Liu, Y., Ge, X.-H., Friedl, G., 2009a. Monitoring Cenozoic climate evolution of northeastern Tibet: stable isotope constraints from the western Qaidam Basin, China. International Journal of Earth SeieneesInt. J. Earth Sci. 98 (5), 1063-1075.

Rieser, A.B., Neubauer, F., Liu, Y., Genser, J., Handler, R., Ge, X.-H., Friedl, G., 2009b. 40Ar/39Ar dating of detrital white mica as a complementary tool for provenance analysis: $\Lambda$ case study from the Cenozoic Qaidam Basin (China) 40Ar/39Ar dating of detrital white mica as a complementary tool for provenance analysis: a case study from the Cenozoic Qaidam Basin (China). In: Sedimentary Processes, Environments and Basins. Blackwell Publishing Ltd., pp. 301-325.

Ritts, B.D., Biffi, U., 2000. Magnitude of post-Middle Jurassic (Bajocian) displacement on the central Altyn Tagh fault system, northwest China. Geologieal Society of Ameriea BulletinGeol. Soc. Am. Bull. 112 (1), 6174.

Ritts, B.D., Biffi, U., 2001. Mesozoic northeast Qaidam basin: Response to contractional reactivation of the Qilian Shan, and implications for the extent of Mesozoic intracontinental deformation in central Asia. MemoirsGeologieal Socien of AmerieaMem. Geol. Soc. Am. 293-316.

Ritts, B.D., Hanson, A.D., Zinniker, D., Moldowan, J.M., 1999. Lower-Middle Jurassic nonmarine source rocks and petroleum systems of the northern Qaidam basin, northwest China. AAPG bulletinAAPG Bull. 83 (12), 1980-2005.

Robinson, D.M., Dupont-Nivet, G., Gehrels, G.E., Zhang, Y., 2003. The Tula uplift, northwestern China: Evidence for regional tectonism of the northern Tibetan Plateau during late Mesozoic early Cenozoie timeThe Tula uplift, northwestern China: evidence for regional tectonism of the northern Tibetan Plateau during late Mesozoic-early_Cenozoic time. Geologieal Soeiety of Ameriea BulletinGeol. Soc. Am. Bull. 115 (1), 35-47.

Rohling, E., Fenton, M., Jorissen, F., Bertrand, P., Ganssen, G., Caulet, J., 1998. Magnitudes of sea-level lowstands of the past 500,000 years. Nature 394 (6689), 162-165.

Rooney, A.D., Yang, C., Condon, D.J., Zhu, M., Macdonald, F.A., 2020. U-Pb and Re-Os geochronology tracks stratigraphic condensation in the Sturtian snowball Earth aftermath. Geology 48 (6), 625-629.

Selby, D., Creaser, R.A., 2003. Re-Os geochronology of organic rich sediments: an evaluation of organic matter analysis methods. Chemieal Geology Chem. Geol. 200 (3), 225-240.

Shi, D.N., Shen, Y., Zhao, W.J., Li, A.B., 2009. Seismic evidence for a Moho offset and south-directed thrust at the easternmost Qaidam-Kunlun boundary in the Northeast Tibetan plateau. Earth and Planetary Seienee LettersEarth Planet. Sci. Lett. 288, 329-334.

Shi, W., Wang, F., Wu, L., Yang, L., Zhang, W., Wang, Y., 2018. A prolonged Cenozoic erosional period in East Kunlun (Western China): constraints of detrital apatite (U-Th)/He ages on the onset of mountain building along the northern margin of the Tibetan Plateau. Journal of Asian Earth Seienees J. Asian Earth Sci. 151, 54-61.

Sobel, E.R., Arnaud, N., Jolivet, M., Ritts, B.D., Brunel, M., 2001. Jurassic to Cenozoic exhumation history of the Altyn Tagh range, northwest China, constrained by $40 \mathrm{Ar} / 39 \mathrm{Ar}$ and apatite fission track thermochronology. Geologieal Society of Ameriea MemoirsGeol. Soc. Am. Mem. 194, 247-267.

Song, T., Wang, X., 1993. Struetural styles and stratigraphie patterns of syndepositional faults in a contrational setting: Examples from Quaidam basin, northwestern ChinaStructural styles and stratigraphic patterns of syndepositional faults in a contractional setting: examples from Quaidam basin, northwestern China. AAPG bulletinAAPG Bull. 77 (1), 102-117.

Staisch, L.M., Niemi, N.A., Hong, C., Clark, M.K., Rowley, D.B., Currie, B., 2014. A Cretaceous-Eocene depositional age for the Fenghuoshan Group, Hoh Xil Basin: implications for the tectonic evolution of the 
northern Tibet Plateau. Tectonics 33 (3), 281-301.

Staisch, L.M., Niemi, N.A., Clark, M.K., Chang, H., 2020. The Cenozeic evolution of erustal shortening and left-lateral shear in the Central East Kunlun Shan: implieations for the uplift History of the Tibetan Plateatthe Cenozoic evolution of crustal shortening and left-lateral shear in the Central East Kunlun Shan: implications for the uplift history of the Tibetan Plateau. Tectonics 39 (9) e2020TC006065.

Sun, Y., 2019. Eenozoie deformation of the Qaidam basin, western ChinaCenozoic Deformation of the Qaidam Basin, Western China. Harvard University 117 pp..

Sun, X., Wang, P., 2005. How old is the Asian monsoon system?-palaeobotanical records from China. Palaeogeography, Palaeoclimatology, Palaeoecology Palaeogeogr. Palaeoclimatol. Palaeoecol. 222 (3), 181-222.

Sun, Z., Feng, X., Li, D., Yang, F., Qu, Y., Wang, H., 1999. Cenozoic Ostracoda and palaeoenvironments of the northeastern Tarim Basin, western China. Palaeogeography, Palaeoclimatology, Palaeoeeology Palaeogeogr. Palaeoclimatol. Palaeoecol. 148 (1), 37-50.

Sun, Z., Yang, Z., Pei, J., Ge, X., Wang, X., Yang, T., Li, W., Yuan, S., 2005. Magnetostratigraphy of Paleogene sediments from northern Qaidam Basin, China: implications for tectonic uplift and block rotation in northern Tibetan plateau. Earth and Planetary Seienee LettersEarth Planet. Sci. Lett. 237 (3), 635-646.

Sun, J., Xu, Q., Huang, B., 2007. Late Cenozoic magnetochronology and paleoenvironmental changes in the

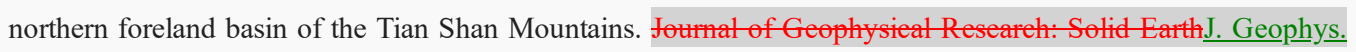
Res. Solid Earth 112 (B4).

Sun, J., Li, Y., Zhang, Z., Fu, B., 2009. Magnetostratigraphic data on Neogene growth folding in the foreland basin of the southern Tianshan Mountains. Geology 37 (11), 1051-1054.

Tapponnier, P., Molnar, P., 1977. Active faulting and tectonics in China. Journal of Geophysieal ResearehJ. Geophys. Res. 82 (20), 2905-2930.

Tapponnier, P., Xu, Z.Q., Roger, F., Meyer, B., Arnaud, N., Wittlinger, G., Yang, J.S., 2001. Oblique stepwise rise and growth of the Tibet Plateau. Science 294 (5547), 1671-1677.

Tian, P., Yuan, W., Yang, X., Feng, Z., Chen, X., Yuan, E., 2020. Multi-stage tectonic events of the Eastern Kunlun Mountains, Northern Tibetan Plateau constrained by fission track thermochronology. Journal of Asian Earth SeiencesJ. Asian Earth Sci. 198, 104428.

Tripathy, G.R., Hannah, J.L., Stein, H.J., Geboy, N.J., Ruppert, L.F., 2015. Radiometric dating of marineinfluenced coal using Re-Os geochronology. Earth and Planetary Seienee LettersEarth Planet. Sci. Lett. 432, $13-23$.

Wang, F., Lob, C.-H., Li, Q., Yeh, M.-W., Wan, J., Zheng, D., Wang, E., 2004. Onset timing of significant unroofing around Qaidam basin, northern Tibet, China: constraints from ${ }^{40} \mathrm{Ar} /{ }^{39} \mathrm{Ar}$ and FT thermochronology on granitoids. Journal of $\Lambda$ sian Earth Seienees J. Asian Earth Sci. 24, 59-69.

Wang, Y., Zhang, X., Wang, E., Zhang, J., Li, Q., Sun, G., 2005. ${ }^{40} \mathrm{Ar} /{ }^{39} \mathrm{Ar}$ thermochronological evidence for formation and Mesozoic evolution of the northern-central segment of the Altyn Tagh fault system in the northern Tibetan Plateau. Geologieal Soeiety of Ameriea BulletinGeol. Soc. Am. Bull. 117 (9-109-10), 1336-1346.

Wang, E., Xu, F.-Y., Zhou, J.-X., Wan, J., Burchfiel, B.C., 2006. Eastward migration of the Qaidam basin and its implications for Cenozoic evolution of the Altyn Tagh fault and associated river systems. Geologieal Society ef Ameriea BulletinGeol. Soc. Am. Bull. 118 (3-4 $\underline{3-4}), 349-365$.

Wang, G., Xiang, S., Wang, A., Garver, J., Wintsch, R., Zhang, K., 2007. Thermochronological constraint to the processes of the east Kunlun and adjacent areas in Mesozoic-early Cenozoic. Earth Seienee-Journal of China University of GeoseieneesEarth Sci. J. China Univ. Geosci. 32 (5), 605-615.

Wang, C., Zhao, X., Liu, Z., Lippert, P.C., Graham, S.A., Coe, R.S., Yi, H., Zhu, L., Liu, S., Li, Y., 2008. Constraints on the early uplift history of the Tibetan Plateau. Proceedings of the National Aeademy of SeiencesProc. Natl. Acad. Sci. 105 (13), 4987-4992.

Wang, A., Wang, G., Zhang, K., Garver, J., 2010a. An early Cenozoic tectonic event in eastern Kunlun orogen, evidence from detrital fission track geochronology. Earth Seience-Journal of China University of GeoseieneesEarth Sci. J. China Univ. Geosci. 35 (5), 645-652.

Wang, L., Xiao, A.C., Gong, Q.L., Liu, D., Wu, L., Zhou, S.P., Shen, Z.Y., Lou, Q.Q., Sun, X.W., 2010b. The unconformity in Miocene sequence of western Qaidam Basin and its tectonic significance. Seienee China Earth SeieneesSci. China Earth Sci. 53 (8), 1126-1133. 
Wang, Y., Nie, J., Zhang, T., Sun, G., Yang, X., Liu, Y., Liu, X., 2010c. Cenozoic tectonic evolution in the western Qaidam Basin inferred from subsurface data. Geoseienees JournalGeosci. J. 14 (4), 335-344.

Wang, C.S., Gao, R., Yin, A., Wang, H., Zhang, Y.X., Guo, T.L., Li, Q.S., Li, Y.L., 2011. A mid-erustal straintransfer model for continental deformation: $A$ new perspective from high-resolution deep seismic-reflection profiling across NE Tibet $\underline{A}$ mid-crustal strain-transfer model for continental deformation: a new perspective from high-resolution deep seismic-reflection profiling across NE Tibet. Earth and Planetary Seienee LettersEarth Planet. Sci. Lett. 306 (3), 279-288.

Wang, C., Dai, J., Zhao, X., Li, Y., Graham, S.A., He, D., Ran, B., Meng, J., 2014. Othard-g of the Fibetan Plateau during the Cenozoic: A review Outward-growth of the Tibetan Plateau during the Cenozoic: a review. Tectonophysics $621,1-43$.

Wang, Y., Zheng, J., Zheng, Y., Liu, X., Sun, G., 2015. Paleoeene-Early Eoeene uplift of the Altyn Tagh Mountain: Evidenee from detrital zireon fission track analysis and seismie seetions in the northwestern Qaidam basinPaleocene-Early_Eocene uplift of the Altyn Tagh Mountain: evidence from detrital zircon fission track analysis and seismic sections in the northwestern Qaidam basin. Journal of Geophysieal Researeh: Solid EarthJ. Geophys. Res. Solid Earth 120 (12), 8534-8550.

Wang, F., Feng, H., Shi, W., Zhang, W., Wu, L., Yang, L., Wang, Y., Zhang, Z., Zhu, R., 2016a. Relief history and denudation evolution of the northern Tibet margin: constraints from 40Ar/39Ar and (U-Th)/He dating and implications for far-field effect of rising plateau. Tectonophysics 675, 196-208.

Wang, W., Zhang, P., Pang, J., Garzione, C., Zhang, H., Liu, C., Zheng, D., Zheng, W., Yu, J., 2016b. The Cenozoic growth of the Qilian Shan in the northeastern Tibetan Plateaut: $\Lambda$ sedimentary arehive from the Jiuxi BasinThe Cenozoic growth of the Qilian Shan in the northeastern Tibetan Plateau: a sedimentary archive from the Jiuxi Basin. Journal of Geophysieal Research: Solid EarthJ. Geophys. Res. Solid Earth 121 (4), 2235-2257.

Wang, F., Shi, W., Zhang, W., Wu, L., Yang, L., Wang, Y., Zhu, R., 2017a. Differential growth of the northern Tibetan margin: evidence for oblique stepwise rise of the Tibetan Plateau. Seientifie RepertsSci. Rep. 7, 41164.

Wang, W., Zheng, W., Zhang, P., Li, Q., Kirby, E., Yuan, D., Zheng, D., Liu, C., Wang, Z., Zhang, H., 2017 . Expansion of the Tibetan Plateau during the Neogene. Nature communieationsNat. Commun. 8, 15887.

Wang, Y., Zheng, J., Zheng, Y., 2018. Mesozoic-Cenozoie exhumation history of the Qimen Tagh Range, northeastern margins of the Tibetan Plateatt: Evidenee from apatite fission track analysisMesozoic-Cenozoic exhumation history of the Qimen Tagh Range, northeastern margins of the Tibetan Plateau: evidence from apatite fission track analysis. Gondwana ResearchGondwana Res. 58, 16-26.

Wang, L., MacLennan, S.A., Cheng, F., 2020a. From a proximal-deposition-dominated basin sink to a significant sediment source to the Chinese Loess Plateau: insight from the quantitative provenance analysis on the Cenozoic sediments in the Qaidam basin, northern Tibetan Plateau. Palaeogeography, Palaeclimatology, Palaeeology Palaeogeogr. Palaeoclimatol. Palaeoecol. 556, 109883.

Wang, W., Zheng, D., Li, C., Wang, Y., Zhang, Z., Pang, J., Wang, Y., Yu, J., Wang, Y., Zheng, W., Zhang, H., Zhang, P., 2020b. Eenozoic exhumation of the Qillian Shan in the northeastern Tibetan Plateau: Evidenee From low-temperature thermochronologyCenozoic exhumation of the Qilian Shan in the northeastern Tibetan Plateau: evidence from low-temperature thermochronology. Tectonics 39 (4) e2019TC005705.

Wang, L., Cheng, F., Zuza, A.V., Jolivet, M., Liu, Y., Guo, Z., Li, X., Zhang, C., 2021. Diachronous growth of the Northern Tibetan Plateau derived from flexural modeling. Geophysical Research LettersGeophys. Res. Lett. 48 (8) e2020GL092346.

Wei, Y., Xiao, A., Wu, L., Mao, L., Zhao, H., Shen, Y., Wang, L., 2016. Temporal and spatial patterns of Cenozoic deformation across the Qaidam Basin, Northern Tibetan Plateau. Terra Nova 28 (6), 409-418.

Wu, L., 2011. The Cenozoic teetonic process of eentral segment of the Altyn Tagh Fault and Its basin responseThe Cenozoic Tectonic Process of Central Segment of the Altyn Tagh Fault and Its Basin Response. Zhejiang University, Hangzhou 152 pp.

Wu, L., Xiao, A., Wang, L., Shen, Z., Zhou, S., Chen, Y., Wang, L., Liu, D., Guan, J., 2011. Late JurassieEarly Cretaceous Northern Qaidam Basin, NW China: implieations for the earliest Cretaceous intracontinental teenismLate Jurassic-Early cretaceous Northern Qaidam Basin, NW China: implications for the earliest cretaceous intracontinental tectonism. Eretaeeous ResearehCretac. Res. 32 (4), 552-564.

Wu, L., Xiao, A., Ma, D., Li, H., Xu, B., Shen, Y., Mao, L., 2014. Cenozoic fault systems in southwest Qaidam Basin, northeastern Tibetan Plateau: geometry, temporal development, and significance for hydrocarbon accumulation. AAPG bulletinAAPG Bull. 98 (6), 1213-1234. 
Wu, C., Liu, C., Fan, S., Zuza, A.V., Ding, L., Liu, W., Ye, B., Yang, S., Zhou, Z., 2019a. Structural analysis and tectonic evolution of the western domain of the Eastern Kunlun Range, northwest Tibet. GSA BulletinGSA Bull. 132 (5-65-6), 1291-1315.

Wu, C., Zuza, A.V., Chen, X., Ding, L., Levy, D.A., Liu, C., Liu, W., Jiang, T., Stockli, D.F., 2019b. Tectonics of the eastern Kunlun Range: cenozoic reactivation of a Paleozoic-Early Mesozoic Orogen. Tectonics 38 (5), $1609-1650$.

Wu, C., Zuza, A.V., Zhou, Z., Yin, A., McRivette, M.W., Chen, X., Ding, L., Geng, J., 2019c. MesozoicCenozoic evolution of the Eastern Kunlun Range, central Tibet, and implications for basin evolution during the Indo-Asian collision. Lithosphere 11 (4), 524-550.

Wu, L., Lin, X., Cowgill, E., Xiao, A., Cheng, X., Chen, H., Zhao, H., Shen, Y., Yang, S., 2019d. Middle Miocene reorganization of the Altyn Tagh fault system, northern Tibetan Plateau. GSA BulletingSA Bull. 131 (7-87-8), $1157-1178$.

Wu, C., Li, J., Zuza, A.V., Liu, C., Liu, W., Chen, X., Jiang, T., Li, B., 2020. Cenozoic cooling history and fluvial terrace development of the western domain of the Eastern Kunlun Range, northern Tibet. Palaeogeography, Palaeoclimatology, PalaeoecologyPalaeogeogr. Palaeoclimatol. Palaeoecol. 560, 109971.

Xia, W.C., Zhang, N., Yuan, X.P., Fan, L.S., Zhang, B.S., 2001. Eenozoie Qaidam basin, China: A stronger teetonic inversed, extensional rifted basinCenozoic Qaidam basin, China: a stronger tectonic inversed, extensional rifted basin. AAPG bulletinAAPG Bull. 85 (4), 715-736.

Yan, D.-F., Zhang, L., Han, L., Yang, T., Chen, Y.-Q., 2018. Podocarpium from the Oligocene of NW Qaidam Basin, China and its implications. Review of Palaeobotany and PalynologyRev. Palaeobot. Palynol. 259, 1-9.

Yang, F., 1988. Đistribution of the brackish-salt water ostracods in northwestern Qinghai Plateatt and Its geologieal SignificaneeDistribution of the brackish-salt water ostracods in northwestern Qinghai Plateau and its geological significance. In: Hanai, T., Ikeya, N., Ishizaki, K. (Eds.), Developments in Palaeontology and Stratigraphy. Elsevier, pp. 519-530.

Yang, F., Ma, Z.Q., Xu, T.C., Ye, S.J., 1992. A Tertiary paleomagnetic stratigraphic profile in Qaidam basin (in Chinese with English abstract). Acta Petrolei SinieaActa Pet. Sin. 13 (2), 97-101.

Yang, T., Zhang, L., Li, W., Jia, J., Han, L., Zhang, Y., Chen, Y., Yan, D., 2018. New schizothoracine from Oligocene of Qaidam Basin, northern Tibetan Plateau, China, and its significance. Journal of Vertebrate Paleontology. Vertebr. Paleontol. 38 (2), e1442840.

Yin, A., Rumelhart, P., Butler, R., Cowgill, E., Harrison, T., Foster, D., Ingersoll, R., Qing, Z., Xian-Qiang, Z., Xiao-Feng, W., 2002. Tectonic history of the Altyn Tagh fault system in northern Tibet inferred from Cenozoic sedimentation. Geologieal Soeie of Ameriea BulletinGeol. Soc. Am. Bull. 114 (10), 1257-1295.

Yin, A., Dang, Y.Q., Zhang, M., McRivette, M.W., Burgess, W.P., Chen, X.H., 2007. Cenozoic tectonic evolution of Qaidam basin and its surrounding regions (part 2): Wedge tectonics in southern Qaidam basin and the Eastern Kunlun Range. Geologieal Soeiety of Ameriea Speeial PapersGeol. Soc. Am. Spec. Pap. 433, 369390 .

Yin, A., Dang, Y.Q., Wang, L.C., Jiang, W.M., Zhou, S.P., Chen, X.H., Gehrels, G.E., McRivette, M.W., 2008a. Cenozoic tectonic evolution of Qaidam basin and its surrounding regions (Part 1): The southern Qilian Shan-Nan Shan thrust belt and northern Qaidam basinCenozoic tectonic evolution of Qaidam basin and its surrounding regions (part 1): the southern Qilian Shan-Nan Shan thrust belt and northern Qaidam basin. Geologieal Society of Ameriea BulletinGeol. Soc. Am. Bull. 120 (7-87-8), 813-846.

Yin, A., Dang, Y.Q., Zhang, M., Chen, X.H., McRivette, M.W., 2008b. Cenozoie tectonic evolution of the Qaidam basin and its surrounding regions (Part 3): Struetural geology, sedimentation, and regional tectonie reeonstruetionCenozoic tectonic evolution of the Q a aidam basin and its surrounding regions (part 3): Structural geology,sedimentation, and regional tectonic reconstruction. Geologieal Society of Ameriea BulletinGeol. Soc. Am. Bull. 120 (7-87-8), 847-876.

Yu, L., Xiao, A., Wu, L., Tian, Y., Rittner, M., Lou, Q., Pan, X., 2017. Provenance evolution of the Jurassic northern Qaidam Basin (West China) and its geological implications: evidence from detrital zircon geochronology. International Journal of Earth SeieneesInt. J. Earth Sci. 1-14.

Q18 Yu, J., Pang, J., Wang, Y., Zheng, D., Liu, C., Wang, W., Li, Y., Li, C., Xiao, L., 2019a. Mid-Miocene uplift of the northern Qilian Shan as a result of the northward growth of the northern Tibetan Plateau. Geosphere. 
Yu, J., Zheng, D., Pang, J., Wang, Y., Fox, M., Vermeesch, P., Li, C., Xiao, L., Hao, Y., Wang, Y., $2019 b$.

Miocene range growth Along the Altyn Tagh fault: insights From apatite fission track and (U-Th)/He thermochronometry in the western Danghenan Shan, China Miocene range growth along the Altyn Tagh fault: insights from apatite fission track and ( $\underline{\mathrm{U}-\mathrm{Th}}$ )/He thermochronometry in the western Danghenan Shan, China. Journal of Geophysieal Research: Solid EarthJ. Geophys. Res. Solid Earth 124 (8), 9433-9453.

Yuan, W.M., Zhang, X.T., Dong, J.Q., Tang, Y.H., Yu, F.S., Wang, S.C., 2003. A new vision of the intracontinental evolution of the eastern Kunlun Mountains, Northern Qinghai-Tibet plateau, China. Radiation MeasurementsRadiat. Meas. 36 (1), 357-362.

Yuan, W.M., Dong, J.Q., Wang, S.C., Carter, A., 2006. Apatite fission track evidence for Neogene uplift in the eastern Kunlun Mountains, northern Qinghai-Tibet Plateau, China. Journal of Asian Earth Seienees $\underline{\text { J. Asian }}$ Earth Sci. 27 (6), 847-856.

Zachos, J., Pagani, M., Sloan, L., Thomas, E., Billups, K., 2001. Frends, rhythms, and aberrations in global Climate $65 \mathrm{Ma}$ to PresentTrends, rhythms, and aberrations in global climate $65 \mathrm{Ma}$ to present. Science 292 (5517), 686-693.

Zhang, W., 2007. High-resolution megnetostratigraphy of the Cenozoic Qaidam Basin, implieations for the uplift of Tibetan Plateau (in Chinese with English abstract)High-Resolution Megnetostratigraphy of the Cenozoic Qaidam Basin, Implications for the Uplift of Tibetan Plateau (in Chinese with English Abstract). LanZhou University, Lanzhou.

Zhang, Z., Guo, Z., Li, J., Tang, W., 2012. Mesozoic and Cenozoic uplift-denudation along the Altyn Tagh Fault, Northwestern China: constrains from apatite fission track data. Quaternary Seienees_uaternary_Sci. 32 (3), 499-509.

Zhang, C., Cheng, F., Huang, G., Huang, Y., Xing, C., Guan, B., Zhang, Q., Xu, G., 2013a. Sediment and reservoir characteristics with reservoir evaluation of the Lulehe Formation in Qie 16 block of Kunbei oilfield in Qaidam Basin. Aeta Petrologiea SinieaActa Petrol. Sin. 29 (8), 2883-2894.

Zhang, W., Fang, X., Song, C., Appel, E., Yan, M., Wang, Y., 2013b. Late Neogene magnetostratigraphy in the western Qaidam Basin (NE Tibetan Plateau) and its constraints on active tectonic uplift and progressive evolution of growth strata. Tectonophysics 599, 107-116.

Zhang, B., Zhang, J., Wang, Y., Zhao, H., Li, Y., 2017. Late Mesozoic-Cenozoic exhumation of the Northern Hexi Corridor: constrained by apatite fission track ages of the Longshoushan. Aeta Geologiea Siniea - English EditionActa Geol. Sin. 91 (5), 1624-1643.

Zhang, C., Wu, L., Chen, W., Zhang, Y., Xiao, A., Zhang, J., Chen, S., Chen, H., 2020. Early Cretaceous foreland-like Northeastern Qaidam Basin, Tibetan Plateau and its tectonic implications: insights from sedimentary investigations, detrital zircon $\mathrm{U}-\mathrm{Pb}$ analyses and seismic profiling. Palaegegraphy, Palaeoclimatelogy, Palaeoeology Palaeogeogr. Palaeoclimatol. Palaeoecol. 557, 109912.

Zhao, J., Zeng, X., Tian, J., Hu, C., Wang, D., Yan, Z., Wang, K., Zhao, X., 2020a. Provenance and paleogegraphy of the Jurassic Northwestern Qaidam Basin (NW China): Evidenee from sedimentary records and detrital zireon geochronologyProvenance and paleogeography of the Jurassic Northwestern Q $\underline{\text { aidam Basin }}$ (NW China): evidence from sedimentary records and detrital zircon geochronology. Journal of Asian Earth SeieneesJ. Asian Earth Sci. 190, 104060.

Zhao, X., Zhao, J., Zeng, X., Tian, J., Guo, Z., Wang, C., Wang, D., Hu, C., 2020b. Early-Middle Jurassic paleogeography reconstruction in the Western Qaidam Basin: insights from sedimentology and detrital zircon geochronology. Marine and Petroleum GeologyMar. Pet. Geol. 118, 104445.

Zheng, D., Clark, M.K., Zhang, P., Zheng, W., Farley, K.A., 2010. Erosion, fault initiation and topographic growth of the North Qilian Shan (northern Tibetan Plateau). Geosphere 6 (6), 937-941.

Zheng, D., Wang, W., Wan, J., Yuan, D., Liu, C., Zheng, W., Zhang, H., Pang, J., Zhang, P., 2017. Progressive northward growth of the northern Qilian Shan-Hexi Corridor (northeastern Tibet) during the Cenozoic. Lithosphere 9 (3), 408-416.

Zhou, J.X., Xu, F.Y., Wang, T.C., Cao, A.F., Yin, C.M., 2006. Cenozoie deformation history of the Qaidam Basin, NW China: Results from cross-section restoration and implieations for Qinghai Tibet Plateat

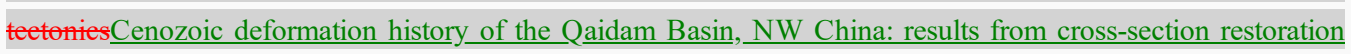
and implications for Qinghai-Tibet Plateau tectonics. Earth and Planetary Seienee LettersEarth Planet. Sci. Lett. $243(1-21-2), 195-210$. 
Zhu, R.X., Potts, R., Xie, F., Hoffman, K.A., Deng, C.L., Shi, C.D., Pan, Y.X., Wang, H.Q., Shi, R.P., Wang,

Y.C., Shi, G.H., Wu, N.Q., 2004. New evidence on the earliest human presence at high northern latitudes in northeast Asia. Nature 431 (7008), 559-562.

Zhu, L., Wang, C., Zheng, H., Xiang, F., Yi, H., Liu, D., 2006. Tectonic and sedimentary evolution of basins in the northeast of Qinghai-Tibet Plateau and their implication for the northward growth of the Plateau. Palaeogeography, Palaeoclimatology, PalaeoecologyPalaeogeogr. Palaeoclimatol. Palaeoecol. 241 (1), 49-60.

Zhu, W., Wu, C., Wang, J., Zhou, T., Li, J., Zhang, C., Li, L., 2017. Heavy mineral compositions and zircon U$\mathrm{Pb}$ ages of Cenozoic sandstones in the SW Qaidam basin, northern Tibetan Plateau: implications for provenance and tectonic setting. Journal of Asian Earth SeieneesJ. Asian Earth Sci. 146, 233-250.

Zhuang, G., Hourigan, J.K., Koch, P.L., Ritts, B.D., Kent-Corson, M.L., 2011a. Isotopic constraints on intensified aridity in Central Asia around 12Ma. Earth and Planetary Seienee LettersEarth Planet. Sci. Lett. 312 (1), 152-163.

Zhuang, G., Hourigan, J.K., Ritts, B.D., Kent-Corson, M.L., 2011b. Cenozoic multiple-phase tectonic evolution of the northern Tibetan Plateau: constraints from sedimentary records from Qaidam basin, Hexi Corridor, and Subei basin, northwest China. Ameriean Journal of SeieneeAm. J. Sci. 311 (2), 116-152.

Zhuang, G., Johnstone, S.A., Hourigan, J., Ritts, B., Robinson, A., Sobel, E.R., 2018. Understanding the geologic evolution of Northern Tibetan Plateau with multiple thermochronometers. Gendwant ResearehGondwana Res. 58, 195-210.

Zuffa, G.G., 1980. Hybrid arenites: their composition and classification. Journal of Sedimentary Researeh $\underline{\underline{J}}$. Sediment. Res. 50 (1), 21-29.

Zuza, A., Yin, A., 2016. Continental deformation accommodated by non-rigid passive bookshelf faulting: an example from the Cenozoic tectonic development of northern Tibet. Tectonophysics 677, 227-240.

\section{Hightlight $\underline{\text { Highlights }}$}

- The old age model fits well the deformation history in the northern Tibetan plateau.

- Cenozoic lithostratigraphic units of the Qaidam basin could be time-transgressive,

- Basement-involved faults accommodate deformation and control basin evolution,

- Qaidam basin has experienced flexural subsidence, outwards expansion, and isolation,

- The interplay between the tectonics and climate determines the basin evolution,

\section{Appendix A.Appendix A Supplementary data \\ Mu国edia Component 1}

Supplementary material

alt-text: Image 1

\section{Queries and Answers}


Query: Please provide caption for Fig. 5.

Answer: Caption for Fig. 5

Images of typical outcrops and drill cores samples of Mesozoic to Cenozoic strata and basement rocks in the Qaidam basin. (a)

Unconformities between the Jurassic and Cretaceous strata in the NE Qaidam basin. (b) Marginal lacustrine coal-bearing Jurassic srata in the NE Qaidam basin. (c) Drilling core samples in the NE Qaidam basin, showing coarse-grained sandstone in the Lulehe Fm. and granite basement rocks. (d) Conglomerates in the Lulehe Fm., eastern Qaidam basin. (e) Lacustrine limestone in the Lower Xiaganchaigou Fm., western Qaidam basin. (f) Organic rich layers in the Upper Xiaganchaigou Fm., western Qaidam basin. (g) Lacustrine to fluvial deposits in the Shangganchaigou Fm., eastern Qaidam basin. (h) Lacustrine sequences in the Xiayoushashan Fm., western Qaidam basin. (i) Mega-yardangs sculpted in mainly lacustrine Shizigou Fm. and fluvial Qigequan Fm., NE Qaidam basin.

\section{Q2}

Query: Your article is registered as belonging to the Special Issue/Collection entitled "Tethyan Tectonics". If this is NOT correct and your article is a regular item or belongs to a different Special Issue please contact p.rajendran.1@elsevier.com immediately prior to returning your corrections.

Answer: Yes

\section{Q3}

Query: Please confirm that given names and surnames have been identified correctly and are presented in the desired order, and please carefully verify the spelling of all authors' names.

Answer: Yes

\section{Q4}

Query: The author names have been tagged as given names and surnames (surnames are highlighted in teal color). Please confirm if they have been identified correctly.

\section{Answer: Yes}

\section{Q5}

Query: Please confirm that the provided email cfff.chengfeng@gmail.com is the correct address for official communication, else provide an alternate e-mail address to replace the existing one, because private e-mail addresses should not be used in articles as the address for communication.

Answer: I confirm that the provided email is the correct address.

Query: Please check whether the designated corresponding author is correct, and amend if necessary. Answer: Yes. The designated two corresponding authors are correct.

\section{Q7}

Query: Please check the hierarchy of the section headings and confirm if correct.

Answer: Yes, it is correct. 
Query: The citation "Rieser et al., 2006c" has been changed to "Rieser et al., 2006b" to match the author name/date in the reference list. Please check if the change is fine in this occurrence and modify the subsequent occurrences, if necessary.

Answer: I am fine with this change.

Q9

Query: Citation "Pan et al., 2013" has not been found in the reference list. Please supply full details for this reference. Answer: The full details for this referenccce is given below:

Pan, B., Li, Q., Hu, X., Geng, H., Liu, Z., Jiang, S., Yuan, W., 2013. Cretaceous and Cenozoic cooling history of the eastern Qilian Shan, north-eastern margin of the Tibetan Plateau: evidence from apatite fission-track analysis. Terra Nova 25, 431-438.

\section{Q10}

Query: Have we correctly interpreted the following funding source(s) and country names you cited in your article: "Lhasa National Geophysical Observation and Research Station; Chinese Academy of Geological Sciences, China; CAS; National Natural Science Foundation of China, China".

Answer: The third funding source is State Key Laboratory of Loess and Quaternary Geology, Institute of Earth Environment, CAS

\section{Q11}

Query: Supplementary caption was not provided. Please check the suggested data if appropriate, and correct if necessary. Answer: I am fine with the suggested data. Thanks.

\section{Q12}

Query: Supplementary caption was not provided. Please check the suggested data if appropriate, and correct if necessary. Answer: I am fine with the suggested data. Thanks.

\section{Q13}

Query: Ref. Pan et al. (2013) was a duplicate and was thus removed from the Reference list. Please check if appropriate. Answer: The reference is:

Pan, B., Li, Q., Hu, X., Geng, H., Liu, Z., Jiang, S., Yuan, W., 2013. Cretaceous and Cenozoic cooling history of the eastern Qilian Shan, north-eastern margin of the Tibetan Plateau: evidence from apatite fission-track analysis. Terra Nova 25, 431-438.

\section{Q14}

Query: Please provide the volume number and page range for the bibliography in Finzel and Rosenblume, 2020.

Answer: volume number: 49

page range: $294-298$

Finzel, E.S., Rosenblume, J.A., 2020. Dating lacustrine carbonate strata with detrital zircon U-Pb geochronology. Geology 49, 294-298.

\section{Q15}

Query: Please provide the volume number and page range for the bibliography in Li et al., 2020.

Answer: This is an error. This reference should be deleted and all Li et al., 2020 in the main text should be changed to Li et al., 
Query: Please provide the volume number and page range for the bibliography in Meng et al., 2020.

Answer: Volume: 18

Page range: $1-9$

Meng, Q.-A., Wang, X., Huo, Q.-L., Dong, Z.-L., Li, Z., Tessalina, S.G., Ware, B.D., McInnes, B.I.A., Wang, X.-L., Liu, T., Zhang, L., 2021. Rhenium-osmium (Re-Os) geochronology of crude oil from lacustrine source rocks of the Hailar Basin, NE

China. Petroleum Science 18, 1-9.

\section{Q17}

Query: Ref. Rieser et al. (2006c) was a duplicate and was thus removed from the Reference list. Please check if appropriate. Answer: No problem of removing it.

\section{Q18}

Query: Please provide the volume number and page range for the bibliography in Yu et al., 2019a. Answer: Volume: 15

Page: $423-432$

Yu, J., Pang, J., Wang, Y., Zheng, D., Liu, C., Wang, W., Li, Y., Li, C., Xiao, L., 2019. Mid-Miocene uplift of the northern Qilian Shan as a result of the northward growth of the northern Tibetan Plateau. Geosphere 15, 423-432. 